HOHENHEIM DISCUSSION PAPERS

IN BUSINESS, ECONOMICS AND SOCIAL SCIENCES

Institute of Economics

DISCUSSION PAPER 12-2017

\title{
HOW DO ENTREPRENEURIAL PORTFOLIOS RESPOND TO INCOME TAXATION?
}

Frank M. Fossen

University of Nevada

Ray Rees

Ludwig-Maximilians-Universität München

Davud Rostam-Afschar

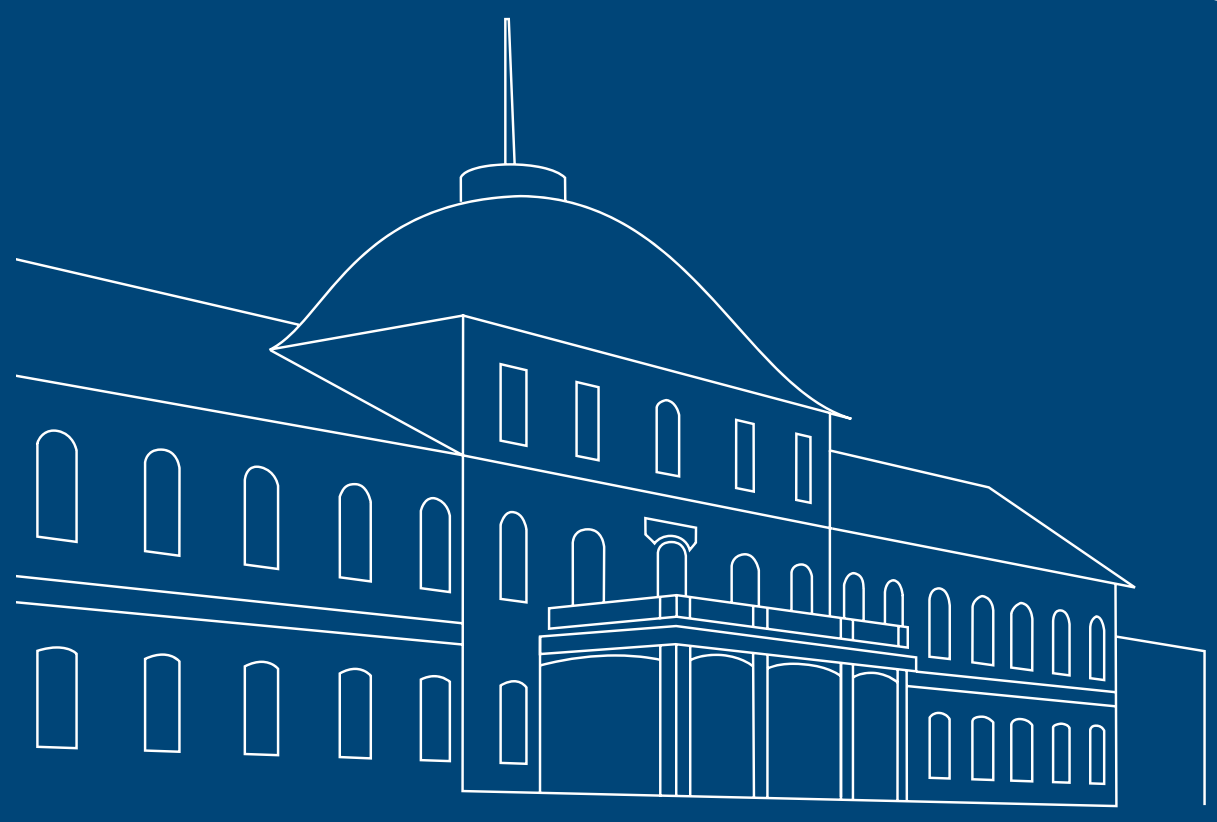

University of Hohenheim

Viktor Steiner

Freie Universität Berlin 


\title{
Discussion Paper 12-2017
}

\section{How Do Entrepreneurial Portfolios Respond to Income Taxation?}

\author{
Frank M. Fossen, Ray Rees, Davud Rostam-Afschar, Viktor Steiner
}

\author{
Download this Discussion Paper from our homepage: \\ https://wiso.uni-hohenheim.de/papers
}

ISSN 2364-2076 (Printausgabe)

ISSN 2364-2084 (Internetausgabe)

Die Hohenheim Discussion Papers in Business, Economics and Social Sciences dienen der schnellen Verbreitung von Forschungsarbeiten der Fakultät Wirtschafts- und Sozialwissenschaften. Die Beiträge liegen in alleiniger Verantwortung der Autoren und stellen nicht notwendigerweise die Meinung der Fakultät Wirtschafts- und Sozialwissenschaften dar.

Hohenheim Discussion Papers in Business, Economics and Social Sciences are intended to make results of the Faculty of Business, Economics and Social Sciences research available to the public in order to encourage scientific discussion and suggestions for revisions. The authors are solely responsible for the contents which do not necessarily represent the opinion of the Faculty of Business, Economics and Social Sciences. 


\title{
How Do Entrepreneurial Portfolios Respond to Income Taxation? ${ }^{\text {th }}$
}

\author{
July 4, 2017 \\ Frank M. Fossen ${ }^{\mathrm{a}}$, Ray Rees ${ }^{\mathrm{b}}$, Davud Rostam-Afschar $^{\mathrm{c}}$, Viktor Steiner $^{\mathrm{d}}$ \\ ${ }^{a}$ Department of Economics, University of Nevada, Reno, NV 89557-0030, USA; DIW Berlin; IZA Bonn \\ ${ }^{b}$ CES, Faculty of Economics, Ludwig-Maximilians-Universität München, Schackstr. 4, 80539 München, Germany \\ ${ }^{c}$ Department of Economics, Universität Hohenheim, 70593 Stuttgart, Germany \\ ${ }^{d}$ Department of Economics, Freie Universität Berlin, Boltzmannstr. 20, 14195 Berlin, Germany
}

\begin{abstract}
We investigate how personal income taxes affect the portfolio share of personal wealth that entrepreneurs invest in their own business. In a reformulation of the standard portfolio choice model that allows for underreporting of private business income to tax authorities, we show that a fall in the tax rate may increase investment in risky entrepreneurial business equity at the intensive margin, but decrease entrepreneurial investment at the extensive margin. To test these hypotheses, we use household survey panel data for Germany eliciting the personal wealth composition in detail in 2002, 2007, and 2012. We analyze the effects of personal income taxes on the portfolio shares of six asset classes of private households, including private business equity. In a system of simultaneous demand equations in first differences, we identify the tax effects by an instrumental variables approach exploiting tax reforms during our observation period. To account for selection into entrepreneurship, we use changes in entry regulation into skilled trades. Estimation results are consistent with the predictions of our theoretical model. An important policy insight is that lower taxes drive out businesses that are viable only due to tax avoidance or evasion, but increase investment in private businesses that are also worthwhile in the absence of taxes.
\end{abstract}

Keywords Taxation · entrepreneurship $\cdot$ portfolio choice $\cdot$ investment

JEL Classification $\mathrm{H} 24 \cdot \mathrm{H} 25 \cdot \mathrm{H} 26 \cdot \mathrm{L} 26 \cdot \mathrm{G} 11$

\footnotetext{
${ }^{2}$ We thank participants at the Workshop on Self-Employment/Entrepreneurship and Public Policy at Oslo Fiscal Studies in 2016 and seminar participants at Freie Universität Berlin, University of Bath, University of Canterbury, University of Nevada, Reno, and Universität Hohenheim, for valuable comments. The usual disclaimer applies.

Email addresses: ffossen@unr.edu (Frank M. Fossen), ray.rees@lrz.uni-muenchen.de (Ray Rees), davud.rostam-afschar@uni-hohenheim.de (Davud Rostam-Afschar), viktor.steiner@fu-berlin.de (Viktor Steiner)
} 


\section{Introduction}

Taxes influence the decisions of households on which assets to hold and how much to invest in each asset type. A growing empirical literature has analysed the effects of personal income taxes on household portfolio allocation (Feldstein 1976; Hubbard 1985; King and Leape 1998; Poterba 2002a,b; Poterba and Samwick 2002; Alan et al. 2010; Ochmann 2014). The literature considers tax effects on investment in assets such as owner-occupied housing, rental property, and various forms of financial assets. However, the literature is mostly silent about the impact of taxes on private business equity, i.e., the share of wealth that entrepreneurial households invest in their own businesses. Closing this knowledge gap is an important task from the perspectives of academics and policymakers. In Germany (the United States), $8 \%$ (9\%) of the population own private business equity, and these entrepreneurs on average allocate as much as $40 \%$ (42\%) of their wealth to their own businesses. Although entrepreneurial households form a minority among households, they hold a large share of aggregate wealth because they are much wealthier on average than other households: The average net worth of entrepreneurs is more than five times as much as that of non-entrepreneurs in Germany and even seven times as much in the United States. ${ }^{1}$ Thus, tax effects on entrepreneurial portfolio allocation may dominate tax effects on aggregate capital allocation in the economy. In modern knowledge-based economies, innovation, economic growth and job creation depend on the willingness of entrepreneurs to take risky investments (Carree and Thurik 2003; Acs and Audretsch 2005; van Praag and Versloot 2007). This underscores the importance of understanding the effects of tax policy on entrepreneurial choice and investment.

Although the empirical results from the extisting literature on household portfolio allocation are far from conclusive, they can generally be rationalized by the standard portfolio choice model. However, when we add entrepreneurial equity to the empirical analysis, the standard theory fails to explain the data. We therefore extend the model by allowing for tax sheltering of private business income. Our extended model, which nests the standard model in case of no sheltering, leads to predictions that are consistent with our empirical findings.

More specifically, we model an entrepreneur's choice of the asset composition of her portfolio. We first present a simple model in which a portfolio consists of a risky and a riskless asset, the returns from which are subject to the same tax rate. We distinguish between the decisions on whether to hold anything of an asset or not- the extensive margin — and, conditional on that, how much of the asset to hold—-the intensive margin. We show that in the standard model, a change in the income tax rate, while it induces a change at the intensive margin, does not change the decision at the extensive margin, as long as the tax rate remains below 100\%. Thus empirical evidence showing that when there is a fall in the tax rate, there is a reduction in the probability of holding the risky asset together with an increase in investment conditional on holding the asset cannot be rationalised in this model. At best it represents a puzzle, at worst a rejection of the model.

However, assuming that tax avoidance or evasion in the form of shifting, concealing or underreporting business income-what we refer to as "sheltering" income from taxation-is relatively less costly than for most other forms of asset, we extend the model to show that a fall in the tax rate reduces the attractiveness of investments that are only profitable when part of their return is sheltered. The reason is that lower taxes reduce the net return to sheltering

\footnotetext{
${ }^{1}$ The U.S. figures are from Gentry and Hubbard (2004).
} 
relative to its cost. This can account for the reduction in investment at the extensive margin. In contrast, investments that are profitable in the absence of taxation become more profitable when the tax rate falls and, to the extent that tax sheltering also takes place for these investments, this would also tend to increase reported income and investment. Therefore, we hypothesize that the effect of a fall in the tax rate on the portfolio share of private business equity is negative at the extensive margin, but positive at the intensive margin.

In our empirical model there are six classes of assets, including own business equity. We provide empirical evidence on how marginal tax rates affect the shares of personal wealth held in business equity as well as the other asset forms. We find that lower marginal personal income tax rates significantly decrease the probability of holding private business equity, but increase the conditional wealth share that entrepreneurs invest in their own business. This is contrary to the standard portfolio model but in line with the tax sheltering model just discussed.

For our estimations, we use the German Socio-economic Panel (SOEP), an annual household survey that collected detailed data on the personal wealth composition in 2002, 2007, and 2012, and a comprehensive tax-benefit microsimulation model for Germany to calculate marginal personal income tax rates. We estimate a system of simultaneous demand equations in first differences eliminating unobserved individual fixed effects. The effects of the endogenous individual tax rate are identified by an instrumental variables approach of Gruber and Saez (2002) exploiting tax reforms and bracket creeping during our observation period. We also use legislation changes on entry regulation into skilled trades in 2004 (see Rostam-Afschar 2014) to account for selection into entrepreneurship. Our results indicate that a decrease in the marginal tax rate by 10 percentage points increases the portfolio share of private business equity conditional on owning a private business by $2.3 \%$ of the average conditional portfolio share (39\%), but decreases the unconditional portfolio share by $2.9 \%$ of the unconditional average (3\%). An important policy insight is that lower taxes drive out businesses that are viable only due to tax sheltering, but increase investment in private businesses that are also worthwhile in the absence of taxes.

One reason why the existing empirical literature analysing tax effects on household portfolio choice listed above has mostly excluded own business equity is that most data bases do not provide this information. An exception is Samwick (2000), who includes private business equity in his empirical portfolio choice analysis using the 1998 wave of the U.S. Survey of Consumer Finances, but he does not focus on this asset type. Another reason why most of the literature has not included private business equity may be that entrepreneurial business assets do not fit into the standard portfolio choice model and require specific considerations not only because of their risky nature, but also because of the potentially important role played by tax sheltering opportunities.

A second related stream of empirical literature investigates effects of income taxes on entrepreneurship as an occupational choice (Bruce 2000; Gentry and Hubbard 2000; Bruce and Mohsin 2006; Cullen and Gordon 2007; Fossen 2009; Fossen and Steiner 2009; Hansson 2012; Wen and Gordon 2014). The literature is far from conclusive, with papers reporting both positive effects of personal income tax rates on entrepreneurial choice (Cullen and Gordon 2007) and negative effects (Hansson 2012). One of the reasons for the inconclusiveness of this literature may be its limitation to the binary occupational choice. The operationalisation of entrepreneurship as an occupational choice is closely related to the extensive margin of entrepreneurial investment that we are explicitly considering in this paper. In our data, more than three quarters of business owners (who report positive private business equity) also indicate that self-employment is their main occupation. However, we go beyond the binary choice model by extending the analysis 
to the intensive margin of entrepreneurial portfolio investment. Our finding of opposite tax effects at the extensive and intensive margins, which we can explain with our extended theoretical model, contributes to reconciling the results from the binary choice literature. Even if we assume that entrepreneurs have a strong preference for self-employment because of the independence and autonomy it brings, our sheltering model still predicts a negative effect of a tax cut at the extensive margin. The cost of that independence and autonomy increases for business investment that is unprofitable in the absence of sheltering, when the return to sheltering, the tax rate, falls.

The paper proceeds as follows. Section 2 presents our theoretical model explaining how tax changes may affect holdings of a risky asset, with different signs at the extensive and intensive margins, and Section 3 goes on to set out our econometric strategy. In Section 4, we provide relevant information on the personal income tax reforms and the reform of entry regulation in Germany that we exploit to identify tax and selection effects. Section 5 describes the panel data we use, and Section 6 presents our empirical results. Section 7 concludes the analysis.

\section{Theoretical Model of Entrepreneurial Portfolio Choice}

Portfolio choice under taxation in the presence of a risky asset such as own business equity has long been discussed in the theoretical literature (Domar and Musgrave 1944; Sandmo 1977; Feldstein and Slemrod 1980; Auerbach and King 1983; Konrad 1991). While this literature has focused on the intensive margin of portfolio investment, another literature stream has evolved that more specifically discusses tax effects on entrepreneurial choice as a decision at the extensive margin (Kanbur 1981; Gentry and Hubbard 2000; Cullen and Gordon 2007). In the following, we develop a portfolio choice model that allows for tax sheltering of private business income and that consistently generates predictions for both the extensive and intensive margins of portfolio choice.

In the standard portfolio choice model, a risk averse investor with given initial wealth maximizes end of period utility by choosing a portfolio consisting of a safe and a risky asset, and will hold a positive amount of the latter if and only if its expected return net of the safe rate of return is positive. Imposing the same proportional rate of income tax on the returns to both assets cannot change this sign, and, a fortiori, reducing this tax rate cannot induce the investor to move to a corner solution in which she would hold none of the risky asset- the net return must vary inversely with the tax rate. Therefore, an empirical observation that shows a fall in the tax rate having this effect cannot be rationalized in this model and so presents a "puzzle", or, more accurately, a rejection of the model.

When the model is applied to a class of decisions for which the risky asset is the business income of an individual entrepreneur however, a straightforward rationalisation of the observation that the tax rate has opposite effects at the extensive and intensive margins suggests itself. If part of the business income can be sheltered in such a way that its net of tax return increases relative to that of the safe asset, the return to which cannot be sheltered, it can happen that a business investment that would not be undertaken in the absence of taxation because its net return is negative could actually become profitable in the presence of a suitably high tax rate, since this is the rate of return to sheltering. ${ }^{2}$ In

\footnotetext{
${ }^{2}$ We are not specifying whether sheltering of business income is due to legal tax avoidance activities such as profit shifting or illegal tax evasion. In practice, it is likely that a mixture of both occurs, although it is of course very hard to find direct evidence due to the very nature of income concealment. However, it is very plausible that income from private businesses, which must be declared by the entrepreneur, can be sheltered more easily than other income types such as wage and salary income or income from interest or dividends, all of which are subject to withholding taxes.
} 
a population of such investments with a given distribution, a reduction in the tax rate could then eliminate the least profitable of them. At the same time, investment in projects whose net expected return in the absence of taxation is positive could be increased, ${ }^{3}$ so that the signs of the effects of the tax reduction at the extensive and intensive margins are the opposite of each other. The following model explores this intuition more rigorously.

We take a single entrepreneur who supplies capital $k \geq 0$ to her own business, and this has a risky return of $\tilde{e}$. In each given state of the world she shelters $\tilde{c} \in[0, k \tilde{e}]$ of this, and $b$ is the holding of the safe asset, with a riskless rate of return of $r$. Note that we are assuming that she never shelters more than actual earnings, but allowing this possibility would simply strengthen the argument. It is also reasonable to assume that she never conceals negative returns.

The income tax rate is $t$ and initial wealth is $W_{0}$. The amount of income sheltered is chosen after the return is realised, and depends on how much is invested and the realised rate of return, as given by the continuously differentiable function $\tilde{c}=\gamma(k, \tilde{e}), \gamma_{k}, \gamma_{\tilde{e}}>0$ and $\gamma(0, \tilde{e})=0$.

It is possible to set up more sophisticated tax sheltering models along the lines of Allingham and Sandmo (1972), Yitzhaki (1974) or Lin and Yang (2001) but this very simple one is sufficient for our results. The idea is that sheltered income can increase with the amount of investment in own business, but also depends on the return in each state, and is bounded above by kẽ in every state. Underlying this function is a trade-off between the return to sheltering, the tax rate $t$, and costs of tax avoidance (tax planning and advising costs) or tax evasion (including costs associated with detection and punishment).

Ignoring taxation and sheltering for the moment, end of period wealth is

$$
\begin{aligned}
\widetilde{W} & =(1+\tilde{e}) k+(1+r)\left(W_{0}-k\right) \\
& =(1+r) W_{0}+(\tilde{e}-r) k
\end{aligned}
$$

and so true taxable (Haig/Simons) income is

$$
\tilde{y}=\widetilde{W}-W_{0}=r W_{0}+(\tilde{e}-r) k .
$$

However, reported taxable income is

$$
\tilde{y}_{R}=\tilde{y}-\tilde{c}
$$

and so tax paid is

$$
T=t\left[r W_{0}+(\tilde{e}-r) k\right]-t \tilde{c}
$$

Thus the entrepreneur's true after tax income is

$$
\tilde{y}_{T}=(1-t) \tilde{y}+t \tilde{c}=(1-t)\left[r W_{0}+(\tilde{e}-r) k\right]+t \gamma(k, \tilde{e})
$$

and true after tax end of period wealth is $\widetilde{W}_{T}=W_{0}+\tilde{y}_{T}$.

Notice that this is implicitly assuming that negative business income can be set against positive income from the safe asset, and that there is full loss offset if total income is negative. We discuss this assumption below and show

\footnotetext{
${ }^{3}$ In general, as is well-known, the effect of a tax reduction on investment in a risky asset with expected return greater than the riskless rate is ambiguous, as it depends on how the risk aversion of the entrepreneur varies with income or wealth. But an increase in that investment is certainly very plausible.
} 
that the main conclusions of the model are not affected by restrictions on the nature of tax offsets such as are usually found, for example in the German economy. ${ }^{4}$

Given a cdf $F(\tilde{e})$ the entrepreneur solves:

$$
\max _{k} \bar{U}=E\left[u\left(\widetilde{W}_{T}\right)\right]
$$

subject to $k \geq 0$.

The FOC is ${ }^{5}$ :

$$
\frac{\partial \bar{U}}{\partial k}=E\left\{u^{\prime}\left(\widetilde{W}_{T}\right)\left[(1-t)(\tilde{e}-r)+t \gamma_{k}\left(k^{*}, \tilde{e}\right)\right]\right\} \leq 0 ; k^{*} \geq 0 ; k^{*} \frac{\partial \bar{U}}{\partial k}=0 .
$$

There are two equilibria of interest. ${ }^{6}$

1. Suppose first $k^{*}=0$, implying also no sheltering. Since $k^{*}=0 \Rightarrow \widetilde{W}_{T}=[1+(1-t) r] W_{0}$, the condition becomes

$$
(1-t) E(\tilde{e}-r) \leq 0
$$

This is a necessary condition for no investment in the business, and is unaffected by the tax rate. If this condition is not satisfied, a positive $k$ will be optimal even without sheltering, as in the standard model.

In the standard portfolio model without the possibility of income sheltering, if this is a local maximum it is also global since at all values of $k$, risk aversion implies

$$
\frac{\partial^{2} \bar{U}}{\partial k^{2}}=E u^{\prime \prime}\left(\widetilde{W}_{T}\right)\left\{[(1-t)(\tilde{e}-r)]^{2}\right\}<0 .
$$

Thus the marginal expected utility lies below zero over the entire domain of $k$.

However, as we now show, in the presence of the possibility of sheltering it need not be the only local maximum, and so is no longer necessarily a global maximum.

2. If $0<k^{*}<W_{0}$ we must have

$$
\left.\frac{\partial \bar{U}}{\partial k}\right|_{k^{*}>0}=E u^{\prime}\left(\widetilde{W}_{T}\right)\left[(1-t)(\tilde{e}-r)+t \gamma_{k}\left(k^{*}, \tilde{e}\right)\right]=0
$$

with the second order condition, now evaluated at $k^{*}>0$, given by

$$
\frac{\partial^{2} \bar{U}}{\partial k^{2}}=E u^{\prime \prime}\left(\widetilde{W}_{T}\right)\left\{\left[(1-t)(\tilde{e}-r)+t \gamma_{k}\right]^{2}+E u^{\prime}\left(\widetilde{W}_{T}\right) t \gamma_{k k}\right\}<0 .
$$

The reason this maximum is now possible is that $\bar{U}$ may no longer fall monotonically with $k$ because of the possibility of sheltering part of the return $k \tilde{e}$, with the amount sheltered increasing with $k$.

For this interior solution to be strictly preferred to the corner solution we must have

$$
E\left[u\left(W_{0}+(1-t)\left(r W_{0}+(\tilde{e}-r) k^{*}\right)+t \gamma\left(k^{*}, \tilde{e}\right)\right)\right]>u\left([1+(1-t) r] W_{0}\right) .
$$

The existence of such an interior maximum for any arbitrary tax rate $t$ is of course not guaranteed. Necessary conditions for an interior local maximum to exist and be superior to $k^{*}=0$ are $^{7}$ :

\footnotetext{
${ }^{4}$ It is possible to formulate a more complicated model without tax offsets for negative values of portfolio income, but our main conclusion, that tax changes can have opposite effects at the extensive and intensive margins, continues to hold.

${ }^{5}$ Asterisks denote optimal values.

${ }^{6}$ An equilibrium is also possible at a corner solution with $k=W_{0}$, but we need not consider this explicitly.

${ }^{7}$ Proof of this is a straightforward application of the Intermediate Value Theorem and is available from the authors on request.
} 
There exists a critical value $k_{C}>0$ such that, at the given tax rate:

$$
\begin{gathered}
E\left[u\left(W_{0}+(1-t)\left(r W_{0}+(\tilde{e}-r) k_{C}\right)+t \gamma\left(k_{C}, \tilde{e}\right)\right)\right]=u\left([1+(1-t) r] W_{0}\right) \\
\left.\frac{\partial \bar{U}}{\partial k}\right|_{k=k_{C}}>0 .
\end{gathered}
$$

In words, there exists a positive $k$-value at which expected utility is equal to that at $k=0$ and is strictly increasing at that point. Intuitively, the gain from sheltering in states of the world where $\tilde{e}>0$ must be sufficient to compensate for negative net returns.

Figure 1 illustrates this. Curve $A A$ corresponds to a level of the tax rate $t_{A}$ such that $k^{*}>0$ is a global maximum, while curve $B B$ corresponds to a tax rate $t_{B}$ at which the entrepreneur is just indifferent between the interior and corner solutions. We assume that $t_{A}>t_{B}$ and argue below that a further tax reduction (to $t_{C}$ ) would cause the corner solution to be strictly preferred, thus having a negative effect at the extensive margin.

If condition (14) is satisfied, the entrepreneur will have a risk premium $\rho_{C}>0$ such that

$$
E\left[(1-t)\left(r W_{0}+(\tilde{e}-r) k_{C}\right)+t \gamma\left(k_{C}, \tilde{e}\right)\right]=(1-t) r W_{0}+\rho_{C}
$$

implying

$$
(1-t) E(\tilde{e}-r)+\frac{t E \tilde{c}}{k_{C}}=\frac{\rho_{C}}{k_{C}} .
$$

This tells us that this case is more likely to arise the higher the tax rate, the greater the expected value of sheltered income, the less risk averse the entrepreneur and the smaller the absolute value of the (negative) expected net return. It is easy to construct examples in which this condition is satisfied.

Note that if $t=1$, as long as any income can be sheltered a $k>0$ must exist such that

$$
E\left[u\left((1-t)\left(r W_{0}+(\tilde{e}-r) k\right)+t \gamma(k, \tilde{e})\right)\right]=E[u(\gamma(k, \tilde{e}))]>u\left((1-t) r W_{0}\right)=0 .
$$

Therefore, by continuity of $\tilde{y}_{T}$ in $t$, there must exist an interval of $t$-values sufficiently close to 1 for which condition (14) is satisfied. On the other hand, at $t=0$ these conditions cannot be satisfied, and again by continuity there will be an interval of $t$-values at which the corner solution is optimal. How large these respective intervals are will be determined by the parameters of the model.

We can then conclude that the population of entrepreneurs could be distributed such that at any tax rate a marginal reduction in the rate will cause some to switch from the interior to the corner solution. These can however only be entrepreneurs for whom $E(\tilde{e}-r) \leq 0$, since those for whom $E(\tilde{e}-r)>0$ will never choose the corner solution regardless of the tax rate. Thus the reduction in tax rate drives out at least some of the entrepreneurs who only invest because of the possibilities of tax sheltering. ${ }^{8}$ The effects on $k$ of tax changes for those entrepreneurs who would be in business in the absence of taxation, with $E(\tilde{e}-r)>0$, are ambiguous, depending as they do on the interplay of income and substitution effects, but it is certainly not a puzzle if these are found to expand their investment when the tax rate falls. 


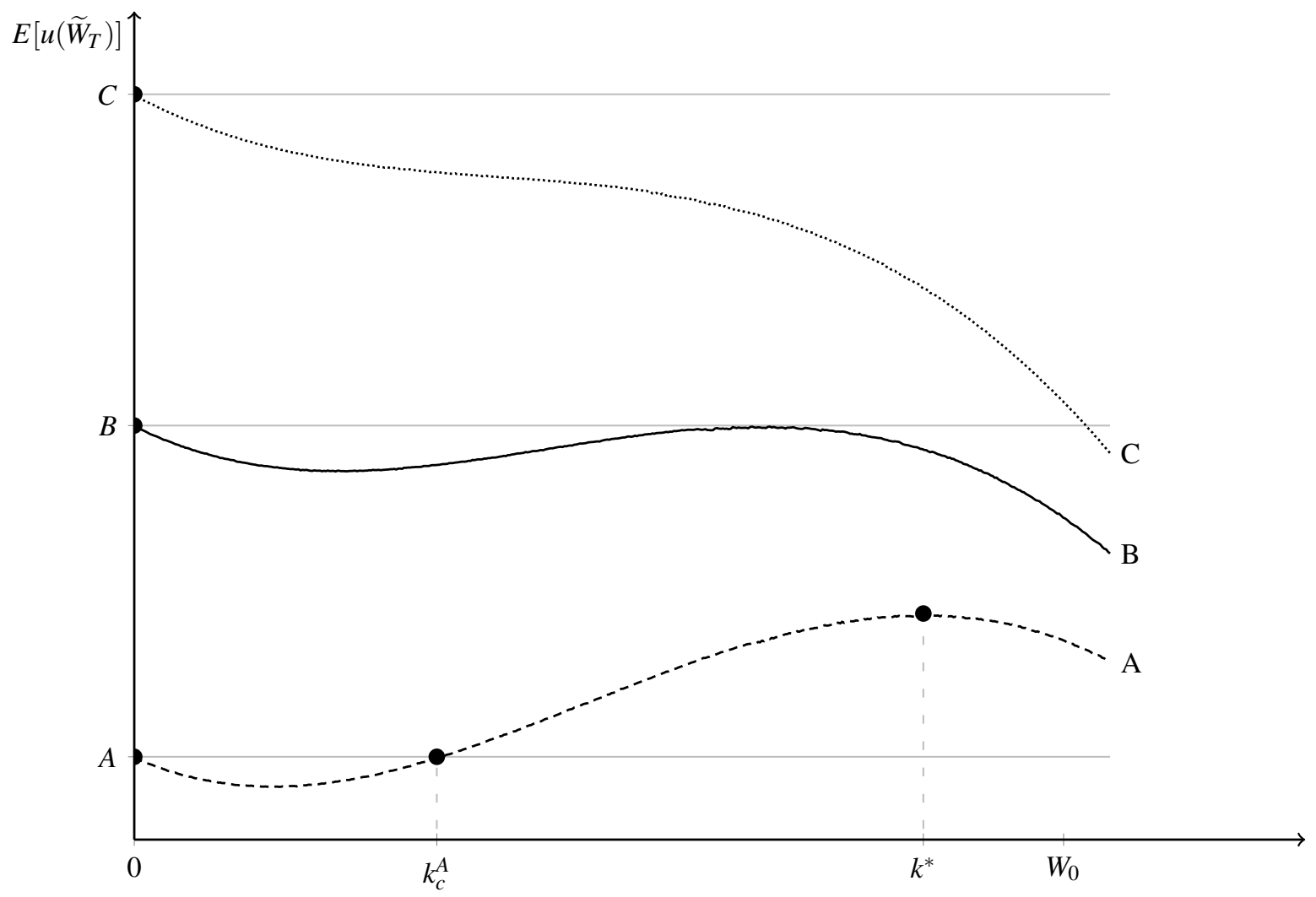

Figure 1: Optimal Investment in Entrepreneurship with Tax Sheltering.

Note: The figure shows an individual's optimal investment in entrepreneurship for a high tax rate (line $A A$ ), a medium tax rate (line $B B$ ), and a low tax rate (line $C C$ ), illustrating an example of an individual for whom entrepreneurship is only worthwhile due to taxation. With the high tax rate, this individual's optimal investment in entrepreneurship is positive $\left(k^{*}>0\right)$. When the tax rate is decreased, the individual reaches a situation where she is just indifferent between no investment or a positive investment in entrepreneurship. A further decrease in the tax rate makes the individual strictly better off when choosing not to be an entrepreneur (line $C C$ ). This example was generated using equally probable good and bad states of the world with returns to the risky asset of $\tilde{e}_{\text {Good State }}=0.5$ and $\tilde{e}_{\text {Bad State }}=-0.6, r=0$, tax rates $t_{A}=0.50, t_{B}=0.45$, and $t_{C}=0.40, W_{0}=100$, preferences implying constant relative risk aversion $u\left(\widetilde{W}_{T}\right)=\widetilde{W}_{T}^{(1-\vartheta)} /(1-\vartheta)-4 \times t$ with $\vartheta=0.5$, and the sheltering function $\gamma(k, \tilde{e})=\max \left[0,\left(k^{2}-0.005 k^{3}\right) \times 0.0096 \times \tilde{e}\right]$.

In this simple model we have assumed full loss offset and a simple proportional income tax. On the other hand in the German tax system tax offset possibilities are restricted and the tax system is piecewise linear. Nevertheless we argue that this simple model is sufficient to resolve the puzzle of why the effects of tax changes can have opposite effects at the extensive and intensive margins. What matters is the possibility of income sheltering over the subset of states of the world in which $\tilde{e}>0$. However, it is also true that the greater the generosity of tax offsets, the more likely it is that an optimum with $k^{*}>0$ will exist.

At the same time, given that the marginal tax rate is determined by total income from all sources, effectively the full loss on one form of income is set against positive income from the other sources. Our sample does not contain

\footnotetext{
${ }^{8}$ This is not to imply that reducing the tax rate is the best way of dealing with tax evasion or avoidance.
} 
individuals with zero or negative income in the aggregate. Moreover, in a piecewise linear tax system, any individual can be modelled as being faced by a linear tax with a virtual lump sum and a constant marginal tax rate. Decisions about allocations of capital and time between different income-earning activities are taken in the light of the net income each yields at the margin, and so the corner solution with the amount of income from a particular source set at zero represents the correct extensive margin for income from that source. This is in contrast to the case of, say, a multinational company deciding on the location of a new factory, or a second earner in a household deciding on whether to go out to work or not, where the average tax rate may be the more relevant one.

We now go on to test the implications of the theoretical model of entrepreneurial portfolio choice by explicitly modeling the extensive and intensive margins in a system of estimated asset demand equations using panel data covering the period 2002 to 2012. Tax rate effects are identified by exogenous changes in the income tax code that took place during the period under analysis.

\section{Empirical Asset Demand Model with Endogenous Tax Rate}

We formulate a system of equations to model demand of individual $i$ in year $t$ for asset class $m$. We distinguish between six asset types: Private business equity, owner-occupied housing, rental property, financial assets (stocks and bonds), life and private pension insurance, and tangible assets. The 6 linear equations

$$
y_{m i t}=X_{i t} \beta_{m}+\mu_{m i}+u_{m i t}
$$

relate the share $y_{m i t}$ of asset class $m$ in the private gross wealth portfolio of individual $i$ to a set of explanatory variables $X_{i t}$ including the marginal tax rate, an unobserved individual specific effect $\mu_{m i}$ capturing individual tastes for certain assets, and a mean-zero error term $u_{\text {mit }}$.

Using panel data on private wealth portfolios, we can eliminate the unobserved fixed effect, in contrast to most of the literature on household portfolio choice, which does not use panel data methods. This is potentially important because unobserved preferences for certain asset classes could well be correlated with tax rates and bias results in cross-sectional estimations. In particular, our approach accounts for unobserved preferences for entrepreneurship such as desire for autonomy included in the fixed effect.

To identify tax effects on the extensive and intensive margins of asset demands, we estimate both the probability that an individual invests in a specific asset class at all and the demand for that asset, conditional on investing in this asset. From an econometric perspective, since most individuals hold incomplete portfolios (King and Leape 1998), for consistent estimation of the coefficient vector $\beta_{m}$ in equation (19) we need to account for the choice of investing in a specific asset class in the first place. This is particularly important in our setup because we extend the set of asset classes considered in King and Leape (1998) by including business equity, which most households do not hold.

To predict selection into ownership we assume that

$$
\begin{aligned}
& y_{m i t}>0 \text { iff } v_{m i t}<Z_{i t} \gamma_{m}+\alpha_{m i}, \\
& y_{m i t}=0 \text { iff } v_{m i t} \geq Z_{i t} \gamma_{m}+\alpha_{m i},
\end{aligned}
$$


where $v_{m i t}$ is an error term and $\alpha_{m i}$ is an individual specific fixed effect that again contains unobserved tastes for certain assets. $Z_{i t}$ is a vector of selection variables that includes $X_{i t}$ and additional variables we discuss further below.

Assume that $E\left(u_{m i t} u_{m j t}\right)=\sigma_{m u}$ and $E\left(v_{m i t} u_{m j t}\right)=\rho \sigma_{v} \sigma_{m u}$ if $i=j$, and that these moments are zero otherwise. To account for the individual fixed effects we extend the selection correction method in Olsen (1980) assuming that $v_{m i t}$ is uniformly distributed over $[0,1]$. Then the predicted probability of selection is

$$
\operatorname{Pr}\left(v_{m i t}<Z_{i t} \gamma_{m}+\alpha_{m i}\right)=Z_{i t} \gamma_{m}+\alpha_{m i}
$$

so that the vector $\gamma_{m}$ can be consistently estimated using the linear probability model in first differences (see Appendix A.1). Note that the standard probit model is not suitable for estimation in first differences. Thus, in a first step, we estimate the selection equation (22) into asset holding using a linear probability model for each asset class and estimate these equations in first differences to allow for individual and asset-class specific effects. This provides estimates of the coefficient vectors $\hat{\gamma}_{m}$.

In a second step, we estimate the conditional expectation of the asset demand system (Shonkwiler and Yen 1999). In our setting the estimation equation, derived in Appendix A.2, is

$$
E\left(y_{m i t} \mid X_{i t}\right)=\left(Z_{i t} \gamma_{m}\right) X_{i t} \beta_{m}+\delta_{m}\left[\left(Z_{i t} \gamma_{m}\right)^{2}-Z_{i t} \gamma_{m}\right] \text {, }
$$

where $\delta_{m}=\rho_{m} \sigma_{m u} \sqrt{3}$ is the coefficient for the selection term, and $\rho_{m}$ measures the correlation of $v_{m i t}$ and $u_{m i t}$. In order to estimate this equation, we transform the vector of variables $X_{i t}$ to $\left(Z_{i t} \hat{\gamma}_{m}\right) X_{i t}$ and include the predicted selection terms $\left(Z_{i t} \hat{\gamma}_{m}\right)^{2}-Z_{i t} \hat{\gamma}_{m}$ as additional regressors. We jointly estimate six asset demand equations using 3SLS in first differences to eliminate the unobserved fixed effect.

The marginal tax rate is endogenous to both the choice to hold a specific asset class and the share of the overall portfolio invested in a given class. The reason is that certain investments may change income, which may influence the marginal tax rate due to the progressivity of the tax schedule. To deal with this endogeneity, we estimate the selection equation (22) and the wealth share equation (23) based on the instrumental variable method. We use the tax-benefit microsimulation model STSM (Steiner et al. 2012) to simulate individual marginal personal income tax rates. ${ }^{9}$ To construct an exogenous instrument for the marginal tax rate, we follow the approach of Gruber and Saez (2002). We first update individual incomes from 2002, the first year in our data, to forecast hypothetical incomes in 2007 and 2012, using the consumer price index. These are the incomes that taxpayers would have received had incomes changed solely due to inflation without any behavioral adjustments. Then we calculate predicted marginal tax rates based on the forecasted incomes using the tax codes of the respective years. We use these predicted marginal tax rates as instrument for the endogenous actual marginal tax rates that are calculated based on observed incomes. Variation in the changes of the predicted marginal tax rates over time exclusively stem from changes in tax laws and bracket creep during our observation period that affect different taxpayers to different degrees due to the nonlinearities and discontinuities of the tax schedule. These effects of tax reforms and inflation are exogenous to the individual.

\footnotetext{
${ }^{9}$ This tax calculator takes into account the details of the German tax and benefit system and its changes over time, including, for example, the rules for income splitting by married couples and child allowances.
} 
Section 4 describes the relevant tax reforms during our period of analysis that provide exogenous variation for the identification of tax effects.

In the portfolio share equation (23), besides the marginal tax rate, the transformed variables $\left(Z_{i t} \hat{\gamma}_{m}\right) X_{i t}$ are also endogenous because $Z_{i t}$ includes the marginal tax rate. As instruments for $\left(Z_{i t} \hat{\gamma}_{m}\right) X_{i t}$ we therefore use modified versions of the transformed variables $\left(Z_{i t}^{I V} \hat{\gamma}_{m}\right) X_{i t}$ where we replace the marginal tax rate with the simulated marginal tax rate. Analogously, we treat the selection term as endogenous as well and use $\left(Z_{i t}^{I V} \hat{\gamma}_{m}\right)^{2}-Z_{i t}^{I V} \hat{\gamma}_{m}$ based on the simulated marginal tax rate as its instrument.

The vector of variables $X_{i t}$ includes controls for time-varying heterogeneity both in the ownership and the portfolio share equations. It is important to control for possibly nonlinear effects of income because income is correlated with the marginal tax rate and is likely to influence portfolio choice. We use monthly gross income, i.e. before tax, because taxes paid are potentially endogenous. Further control variables include net worth and its square ${ }^{10}$ age and its square, the number of children in the household, marital status, the willingness to take risks measured on an 11-point Likert scale, and local GDP per capita (at the level of Germany's 96 Spatial Planning Regions). By eliminating individual fixed effects, we also control any time-invariant characteristics such as gender and ethnicity.

Including the selection term $\left(Z_{i t} \gamma_{m}\right)^{2}-Z_{i t} \gamma_{m}$ in equation (23) controls for selection into holding a particular asset class (most importantly, business ownership) based on unobservables, similar to the inverse Mill's ratio in a standard Heckman selection model. In principle, the selection terms' coefficients $\delta_{m}$ are identified by the nonlinear functional form of the selection term, but identification is stronger when exclusion restrictions exist. Reforms in entry regulation into entrepreneurship in 2004 (see Section 4) are likely to have an effect on the probability of being an entrepreneur, but not on the portfolio share invested in one's own business conditional on being an entrepreneur. Similarly, changes in the local unemployment rate over time affect individual entrepreneurial choice because individuals are pushed into self-employment when it is difficult to find paid employment (Evans and Leighton 1989), but we do not expect an effect on the conditional portfolio share after controlling for changes in regional GDP. Therefore, we include the local unemployment rate (at the Spatial Planning Region level) and interaction terms that capture the effect of the 2004 reform of entry regulation in $Z_{i t}$ but exclude these variables from $X_{i t}$.

Our approach of estimating portfolio choice in two steps is flexible and does not restrict the signs of tax effects to be the same at the extensive margin (asset ownership) and the intensive margin (conditional portfolio share of the same asset). In this respect, our empirical model is similar to that used in King and Leape (1998), although these authors have access to cross-sectional data only and cannot eliminate unobserved individual fixed effects. In contrast, the Tobit model frequently used in the literature (Poterba and Samwick 2002; Alan et al. 2010; Fossen and RostamAfschar 2013) implicitly imposes the restriction that the sign be the same at both margins. Since our theoretical model allows for opposing signs of tax effects at the extensive and intensive margins, it is important to use a general empirical specification that does not impose such a restriction.

\footnotetext{
${ }^{10} \mathrm{Net}$ worth is gross wealth, i.e. the sum of all assets, minus liabilities. We do not include gross wealth as a control variable because the leverage decision is presumably endogenous.
} 


\section{Identification of Tax and Selection Effects Through Legislation Changes}

\subsection{Personal Income Tax Reforms}

To identify the effects of marginal personal income tax (PIT) rates on portfolio choice, we rely on changes in the tax code over time. The changes in marginal tax rates are of different magnitudes for different persons at different points in time and can be considered exogenous for the individual. In this section, we briefly describe the relevant German tax reforms that provide quasi-experimental variation in our time period of analysis (2002-2012). We simulate all the details in the German tax laws and their changes over time to calculate individual marginal tax rates.

Germany follows the principle of comprehensive income taxation to a large extent. The same PIT schedule is applied for most income sources such as wage and salary income or profits from self-employment and unincorporated businesses. Profits of unincorporated businesses are passed through to their owners and are subject to the owners' PIT (transparent taxation). In contrast, corporations are legal entities and subject to a flat corporate income tax. Unincorporated businesses are much more important in Germany than in other countries. In 2012, only $13 \%$ of the enterprises in Germany that were large enough to pay turnover tax (generally when the turnover exceeds 17,500 Euro per year) were incorporated (German Federal Statistical Office 2016). Including entrepreneurs with lower turnover, who are almost exclusively unincorporated, would shrink the share of incorporated firms even more, although no exact statistics are available. Therefore, in our analysis, we focus on unincorporated businesses.

The PIT schedule is directly progressive. After a basic allowance, there are two progressive zones with continuously increasing marginal tax rates, followed by a tax bracket with a constant marginal tax rate. In 2007 , an additional bracket was introduced ("rich tax", see below). On top of income tax, the so-called "solidarity surcharge" is levied at a rate of $5.5 \%$ of the PIT liability for higher incomes, initially introduced to finance the reunification of Germany.

The personal income tax underwent several reforms between 2002 and 2012. Figure 2 displays the statutory marginal PIT rates for unmarried persons in 2002, 2007 and 2012, the three years we use in our empirical analysis. The top marginal income tax rate was reduced from $48.5 \%$ in 2003 to $42 \%$ in 2005 . The "rich tax" reform in 2007 introduced an additional tax bracket with a new top marginal income tax rate of $45 \%$ for incomes in excess of 250,000 Euro (not visible in the figure). The lowest marginal tax rate was decreased from $19.9 \%$ in 2003 to $15 \%$ in 2005 and further to $14 \%$ in 2009 . The basic allowance was raised several times and amounted to 7235 Euro in 2002, 7664 Euro in 2007 and 8004 Euro in 2012 for a single taxpayer and double these amounts for a married couple filing jointly.

Another tax reform was implemented in 2009. Before this date, interest and dividend income were taxed jointly with income from other sources using the PIT schedule. For dividend income, a shareholder tax relief of $50 \%$ was applied to account for taxes already paid by the corporation (corporate income tax plus solidarity surcharge and local business tax). From 2009 on, a separate final withholding tax for interest and dividend income was introduced instead at a flat rate of $25 \%$ plus solidarity surcharge. In turn, the shareholder relief for dividends was abolished, so dividends were effectively taxed at a similar rate as before, taking into account taxes paid at the corporation level.

Since 2008, unincorporated partnerships have the option to tax retained earnings at a rate of $28.25 \%$ instead of the personal tax rate of the PIT schedule. Once the profit is withdrawn, a follow-up tax of $25 \%$ is due. This option is 


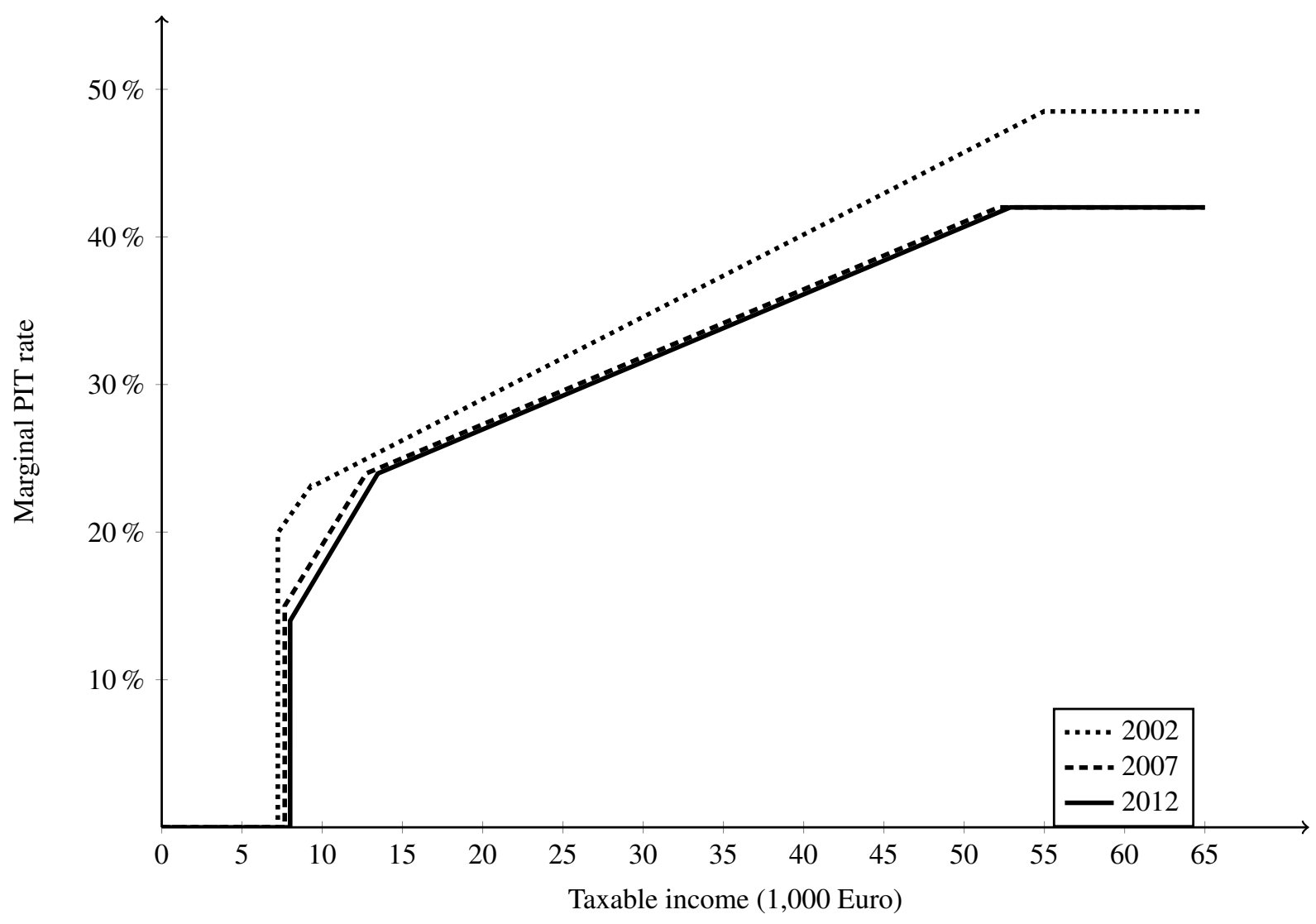

Figure 2: Personal Income Tax Reforms in Germany.

Note: Statutory marginal PIT rates for unmarried persons in 2002, 2007 and 2012.

therefore only attractive for a small number of entrepreneurs who face high marginal tax rates and who intend to retain their profits for a long time. ${ }^{11}$

In the German PIT, apart from setting losses against positive income from other sources, losses can also be carried back to the previous year or carried forward for an unlimited number of years. While losses below 1 million Euro ( 2 million in case of married couples) can by carried forward in full, since 2004 only $60 \%$ of the part of a loss that exceeds these thresholds can be carried forward. Since the thresholds are fairly large, these loss offset restrictions are hardly relevant for the entrepreneurs in our sample, who have a mean monthly income of 4,527 Euro (see Table 3).

The changes in the PIT schedule generated quite substantial variation in the shifts of marginal PIT rates for different taxpayers over time. For instance, because for married couples joint filing is the rule, the tax bracket applicable for a person depends on the earnings of the spouse. Jessen et al. (2017) show marginal tax rates and budget constraints for singles and married couples and provide a comprehensive overview of the German tax and transfer system. Since the PIT schedule is not adjusted for inflation in Germany, bracket creep generates additional cross-sectional variation in changes of marginal PIT rates over time, because the effects of bracket creep are largest in the progressive zones of the tax schedule.

\footnotetext{
${ }^{11}$ See Fossen and Simmler (2016) for details on the final withholding tax and the tax option for retained earnings.
} 


\subsection{Reform of Entry Regulation Into Entrepreneurship}

To control for selection into entrepreneurship (extensive margin), we exploit exogenous variation in entry regulation for certain occupations in crafts and trades. ${ }^{12}$ This group of entrepreneurs amounts to about $19 \%$ of all entrepreneurs in our sample. ${ }^{13}$

Table 1: Reform of Entrepreneurial Entry Regulation For Craft and Trade Occupations

\begin{tabular}{|c|c|c|c|}
\hline Group & Change in Entry Regulation in 2004 & $\%$ of all Entrep. & Example Occupations \\
\hline $\mathrm{AC}$ & Craft and trade occupation with no change & 0.3 & $\begin{array}{l}\text { Chimney sweeps, optometrists, hearing aid } \\
\text { audiologists, orthopedic technicians, dental technicians }\end{array}$ \\
\hline A1 & Relaxation through "senior journeyman rule" & 10.1 & $\begin{array}{l}\text { Roofers, surgical instrument makers, gunsmiths, } \\
\text { plumbers, gas and water fitters, joiners, pastry cooks }\end{array}$ \\
\hline $\mathrm{A} 2$ & In addition, frequent exemptions for "easy jobs" & 3.8 & $\begin{array}{l}\text { Masons and concreters, painters and varnishers, } \\
\text { metalworkers, motor vehicle body and vehicle } \\
\text { construction mechanics, bike mechanics, information } \\
\text { electronics technicians, vehicle technicians, butchers }\end{array}$ \\
\hline B1 & Abolishment of entry requirement & 4.9 & $\begin{array}{l}\text { Tile and mosaic layers, coppersmiths, } \\
\text { turners, tailors, millers, photographers }\end{array}$ \\
\hline
\end{tabular}

Note: Some occupations that are legally not classified as crafts occupations may be included in the same occupational classification code in our data.

Market entry for prospective entrepreneurs in craft trades has been strictly regulated in Germany. Before 2004, and dating back to 1935 , setting up an own crafts business was conditional on having obtained an educational qualification called "Meister" (master craftsman) in 94 occupations listed as A-occupations in the German Trades and Crafts Code. Obtaining this qualification is associated with significant costs. Full-time courses to prepare for the Meister exam take 1-3 years, and the overall costs range from 4000 to 10,000 Euro depending on the occupation. In January 2004, this entry regulation underwent a dramatic change. In many occupations that had required a Meister qualification for market entry, the educational requirement was completely abolished (B1 occupations) or relaxed by allowing "senior journeymen" with six years of relevant work experience to start up without a Meister degree (A1 and A2 occupations). Furthermore, a new rule allowed the exemption of "easy jobs" from the entry requirement. A2 occupations are defined as a group that we conjecture to often make use of this rule, so the entry requirement could be further loosened for this group in practice. Table 1 summarizes the changes in the entry regulation for the occupation groups and lists examples of occupations. Rostam-Afschar (2014) analyses the effects of this reform on entry rates into entrepreneurship and estimates significant effects for B1 and A1 occupations. We account for this reform by including interaction terms of the four occupation group dummies (AC, A1, A2, B1; omitted base category: no craft or trade occupation) with a post reform dummy (years 2004 and later) in the selection equations.

\section{Panel Data with Private Business Equity}

For our analysis of portfolio choice we require individual panel data reporting private asset holdings including private business equity. The data must provide sufficient information on various income sources and the household

\footnotetext{
${ }^{12}$ In addition, we use changes in regional unemployment rates over time for identification of selection effects, as discussed in Section 3.

${ }^{13}$ Due to some classification ambiguity, this might include some occupations that are legally not defined as crafts occupations.
} 
situation for detailed tax-benefit simulation. It must also report occupations at a detailed level and include control variables important for entrepreneurship such as risk attitudes (Caliendo et al. 2009).

Table 2: Entrepreneurial and Non-entrepreneurial Balance Sheets

\begin{tabular}{|c|c|c|c|c|c|c|c|}
\hline & & \multicolumn{3}{|c|}{ Entrepreneurs } & \multicolumn{3}{|c|}{ Non-Entrepreneurs } \\
\hline \multicolumn{2}{|c|}{ Personal Assets and Liabilities } & $\begin{array}{r}\text { Mean assets } \\
(\text { Euro })\end{array}$ & $\begin{array}{l}\text { Percentage of } \\
\text { gross wealth }\end{array}$ & $\begin{array}{r}\text { Percentage of } \\
\text { owners }\end{array}$ & $\begin{array}{r}\text { Mean assets } \\
\text { (Euro) }\end{array}$ & $\begin{array}{l}\text { Percentage of } \\
\text { gross wealth }\end{array}$ & $\begin{array}{r}\text { Percentage of } \\
\text { owners }\end{array}$ \\
\hline I & Financial assets & 51,061 & 10.5 & 59.2 & 16,291 & 23.0 & 57.9 \\
\hline II & Ownership equity & 206,263 & 40.0 & 100.0 & 0 & 0.0 & 0.0 \\
\hline III & Contractual savings & 35,943 & 13.4 & 74.7 & 12,637 & 30.8 & 70.3 \\
\hline IV & Tangible assets & 3,588 & 0.8 & 13.4 & 815 & 1.7 & 7.4 \\
\hline \multirow[t]{3}{*}{$\mathrm{V}$} & Real estate & & & & & & \\
\hline & Primary house or apartment & 155,648 & 26.0 & 52.6 & 101,886 & 38.6 & 47.9 \\
\hline & Other (rental) property & 152,835 & 9.2 & 29.3 & 25,031 & 6.0 & 12.8 \\
\hline \multicolumn{2}{|c|}{ Gross wealth } & 519,565 & 100.0 & 100.0 & 109,726 & 100.0 & 100.0 \\
\hline \multirow[t]{3}{*}{ VI } & Mortgages & & & & & & \\
\hline & On primary house or apart. & 38,125 & 8.9 & 33.3 & 29,506 & 13.0 & 32.6 \\
\hline & On other (rental) property & 47,479 & 3.9 & 15.9 & 8,509 & 3.7 & 7.1 \\
\hline VII & Other liabilities & 13,904 & 20.8 & 30.4 & 3,158 & 69.4 & 23.1 \\
\hline \multicolumn{2}{|c|}{ Total Liabilities } & 99,507 & 33.6 & 62.7 & 41,173 & 86.1 & 50.9 \\
\hline \multicolumn{2}{|c|}{ Net worth } & 441,494 & 67.1 & 95.3 & 82,229 & 15.4 & 91.4 \\
\hline
\end{tabular}

Note: Pooled averages of 1,135 entrepreneur-years and 13,409 non-entrepreneur-years based on the SOEP waves 2002, 2007, and 2012, using population weights provided by the SOEP. The percentages of total gross wealth are means over individual percentage shares in gross wealth portfolios. The large average share of other liabilities in gross wealth for non-entrepreneurs is driven by individuals who have very small gross wealth, but large liabilities. Financial assets include savings balance, savings bonds, bonds, shares or investments, ownership equity commercial enterprise, i.e. a company, a shop, an office, a practice or an agricultural enterprise, contractual savings life insurance or private retirement insurance policies, tangible assets gold, jewelry, coins or valuable collections, other liabilities do not include mortgages or building loans.

These requirements are fulfilled by the SOEP, a representative annual panel survey covering more than 20,000 individuals living in more than 10,000 households in Germany. Wagner et al. (2007) provide a detailed description of the data. The waves of 2002, 2007 and 2012 included a special module collecting detailed information on private wealth. The interviewers asked for the current market values of the most important asset and liability types of private households. The items include personally owned real estate (owner-occupied housing, property rented out, mortgage debt), financial assets, private life and pension insurance, tangible assets, consumer credits, and, most importantly for this analysis, private business equity (net market value, own share in case of a business partnership). All information is elicited at the level of the individual respondent. When an asset is owned by more than one person, e.g., a house owned by a couple, the respondents are asked to indicate which share they own. Therefore, our analysis is on the individual, not the household level. ${ }^{14}$

We define an entrepreneur as a person with strictly positive holdings of own business equity. We restrict our sample to persons between 25 and 65 years of age and exclude those not in the labour force, the unemployed, students, and pensioners. By excluding the unemployed, we focus on persons who have the choice between work in wage and salary employment or entrepreneurship, thus those who become entrepreneurs are likely to do so because they perceive a market opportunity (Fairlie and Fossen 2017). This relates our concept of entrepreneurship more closely to innovation and growth.

\footnotetext{
${ }^{14}$ We use directly observed information on asset holdings only. Using imputations provided by the SOEP increases the size of our final estimation sample only slightly and our estimation results do not change much.
} 
Table 3: Descriptive Statistics

\begin{tabular}{|c|c|c|c|c|c|}
\hline \multirow[t]{2}{*}{ Variable } & \multirow[t]{2}{*}{ Unit } & \multicolumn{2}{|c|}{ Entrepreneurs } & \multicolumn{2}{|c|}{ Non-Entrepreneurs } \\
\hline & & Mean & Std. dev. & Mean & Std. dev. \\
\hline Marginal tax rate & $\%$ & 38.2 & 12.9 & 38.1 & 22.5 \\
\hline Marginal tax rate using updated income (IV) & $\%$ & 37.8 & 19.8 & 36.8 & 23.0 \\
\hline Real gross income per month & Euro (2005 prices) & 4,527 & 5,121 & 2,618 & 1,989 \\
\hline Real net worth & Euro (2005 prices) & 418,980 & $1,471,572$ & 78,033 & 172,801 \\
\hline Age & Years & 45.2 & 9.3 & 43.1 & 10.0 \\
\hline Married & $\%$ & 66.7 & & 65.0 & \\
\hline Number of children in household & Integer & 0.64 & 0.92 & 0.55 & 0.86 \\
\hline Willingness to take risks & Scale $0-10$ & 5.90 & 2.12 & 4.86 & 2.11 \\
\hline Higher technical college or similar & $\%$ & 28.7 & & 26.2 & \\
\hline University degree & $\%$ & 39.6 & & 23.4 & \\
\hline GDP per capita & 1,000 Euro & 30.3 & 9.0 & 29.9 & 8.5 \\
\hline Regional unemployment rate & $\%$ & 8.5 & 3.9 & 8.5 & 4.0 \\
\hline
\end{tabular}

Note: Pooled averages of 1,135 entrepreneur-years and 13,409 non-entrepreneur-years based on the SOEP waves 2002, 2007, and 2012, using population weights provided by the SOEP. Standard deviations are not shown for binary variables.

Table 2 shows private wealth balance sheets of entrepreneurs and non-entrepreneurs, respectively. On average, entrepreneurs' net worth is more than five times as large as that of non-entrepreneurs. Entrepreneurs hold very undiversified portfolios: On average, they invest $40 \%$ of their gross wealth in their own business. This is very similar to observations made for the United States (Gentry and Hubbard 2004). ${ }^{15}$ By definition, non-entrepreneurs do not own any private business equity. They invest the largest share of their gross wealth in owner-occupied housing.

Table 3 summarizes means of other individual characteristics used in our analysis by entrepreneurial status. Entrepreneurs have higher monthly income on average than non-entrepreneurs, which is in line with their larger net worth. However, their marginal PIT rate is only slightly larger, which may partly be due to the fact that they are more likely to be married and have a larger number of children on average. The large standard deviations show the substantial cross-sectional variation in marginal tax rates. Entrepreneurs also self-report a higher willingness to take risks on an 11-point scale from 0 (completely unwilling) to 10 (fully willing).

\section{Empirical Portfolio Choice Results}

\subsection{Extensive Margin}

We begin the discussion of the results by presenting the first estimation step, the regressions of selection into ownership of the six different asset classes. Table 4 shows the estimation results (with standard errors robust to clustering at the individual level). Each column represents a separately estimated linear probability model, where the dependent variable is a dummy that is one if a person has strictly positive holdings of the asset class indicated at the column head and zero otherwise. The equations are estimated using the IV method in first differences. The marginal tax rate is treated as endogenous. The instrument is the simulated marginal tax rate based on each year's tax code, but

\footnotetext{
${ }^{15}$ Fossen $(2011,2012)$ and Fossen and Rostam-Afschar (2013) discuss possible reasons why entrepreneurs hold these undiversified portfolios. In particular, Fossen (2011) finds that lower average risk aversion of entrepreneurs may explain their risky portfolio choices.
} 
exogenously updated individual income from 2002 (see Section 3). The instrument is relevant, as indicated by the first stage $F$-statistic of $25.9 .^{16}$

Table 4: Ownership Probabilities of Asset Classes

\begin{tabular}{|c|c|c|c|c|c|c|}
\hline & Business equity & Owner Housing & Rental Property & Financials & Life Insurance & Tangible Assets \\
\hline \multirow[t]{2}{*}{ Marginal tax rate } & $0.1189 *$ & -0.0576 & $-0.2069 * *$ & -0.0312 & -0.0786 & 0.0650 \\
\hline & $(0.0617)$ & $(0.0769)$ & $(0.0868)$ & $(0.1442)$ & $(0.1254)$ & $(0.0921)$ \\
\hline \multirow[t]{2}{*}{ Local unempl. rate } & -0.0027 & 0.0042 & -0.0038 & 0.0078 & 0.0028 & -0.0018 \\
\hline & $(0.0021)$ & $(0.0035)$ & $(0.0032)$ & $(0.0048)$ & $(0.0045)$ & $(0.0030)$ \\
\hline \multirow[t]{2}{*}{ Occupations A $1 \times \geq 2004$} & $0.0351 *$ & 0.0340 & -0.0413 & -0.0266 & -0.0032 & 0.0068 \\
\hline & $(0.0213)$ & $(0.0278)$ & $(0.0301)$ & $(0.0418)$ & $(0.0345)$ & $(0.0183)$ \\
\hline \multirow[t]{2}{*}{ Occupations A2 $\times \geq 2004$} & 0.0450 & $0.0806^{*}$ & -0.0365 & 0.0934 & 0.0129 & $0.0427 *$ \\
\hline & $(0.0308)$ & $(0.0417)$ & $(0.0328)$ & $(0.0603)$ & $(0.0651)$ & $(0.0248)$ \\
\hline \multirow[t]{2}{*}{ Occupations AC $\times \geq 2004$} & -0.0815 & $-0.1074^{*}$ & 0.0741 & -0.0143 & 0.0234 & 0.0011 \\
\hline & $(0.0607)$ & $(0.0644)$ & $(0.1140)$ & $(0.0940)$ & $(0.1140)$ & $(0.1356)$ \\
\hline \multirow[t]{2}{*}{ Occupations B $1 \times \geq 2004$} & -0.0151 & 0.0104 & -0.0418 & 0.0033 & -0.0013 & -0.0058 \\
\hline & $(0.0176)$ & $(0.0272)$ & $(0.0309)$ & $(0.0497)$ & $(0.0449)$ & $(0.0321)$ \\
\hline \multirow{2}{*}{ Gross income } & $0.1586 * *$ & -0.0266 & $0.1245^{* *}$ & $0.2345 * * *$ & $0.1857 * * *$ & 0.0326 \\
\hline & $(0.0646)$ & $(0.0501)$ & $(0.0606)$ & $(0.0851)$ & $(0.0686)$ & $(0.0577)$ \\
\hline \multirow[t]{2}{*}{ Gross inc. sq. } & -0.0136 & 0.0072 & $-0.0107 *$ & $-0.0163^{*}$ & $-0.0216 * * *$ & -0.0027 \\
\hline & $(0.0096)$ & $(0.0060)$ & $(0.0055)$ & $(0.0088)$ & $(0.0070)$ & $(0.0052)$ \\
\hline \multirow[t]{2}{*}{ Net worth } & $0.6152 * * *$ & $1.3759 * * *$ & $1.1622 * * *$ & 0.2274 & $0.5284 * *$ & 0.1018 \\
\hline & $(0.2296)$ & $(0.3053)$ & $(0.3036)$ & $(0.2303)$ & $(0.2279)$ & $(0.1701)$ \\
\hline \multirow{2}{*}{ Net worth sq. } & $-0.0686^{*}$ & $-0.1700 * * *$ & $-0.1285^{* * *}$ & -0.0374 & -0.0432 & 0.0194 \\
\hline & $(0.0379)$ & $(0.0370)$ & $(0.0347)$ & $(0.0300)$ & $(0.0267)$ & $(0.0192)$ \\
\hline Further controls & $\checkmark$ & $\checkmark$ & $\checkmark$ & $\checkmark$ & $\checkmark$ & $\checkmark$ \\
\hline First-differenced observations & 3,979 & 3,979 & 3,979 & 3,979 & 3,979 & 3,979 \\
\hline$F$-test income terms ( $p$-val.) & 0.0446 & 0.3295 & 0.0972 & 0.0085 & 0.0078 & 0.6814 \\
\hline$F$-test wealth terms ( $p$-val.) & 0.0256 & 0.0000 & 0.0005 & 0.4469 & 0.0261 & 0.0000 \\
\hline$F$-test selection var.: ( $p$-val.) & 0.0519 & 0.1772 & 0.4887 & 0.2326 & 0.9635 & 0.5710 \\
\hline First stage $F$ statistic & 25.8651 & 25.8651 & 25.8651 & 25.8651 & 25.8651 & 25.8651 \\
\hline Mean ownership prob. & 0.0840 & 0.5412 & 0.1646 & 0.5933 & 0.7081 & 0.0854 \\
\hline
\end{tabular}

Note: Linear probability models of ownership of asset classes (separate IV regressions in first differences). The dependent variable is one if a person owns a strictly positive amount of the asset class indicated at the column head and zero otherwise. The marginal tax rate is treated as endogenous. Instrumental variable: the simulated marginal tax rate using exogenously updated individual income from 2002 and the contemporaneous tax code. Estimated in first differences to eliminate individual fixed effects. The occupation groups are defined in Table 1. Gross income is in 10,000 Euro and net worth in 10 mill. Euro, both in prices of 2005. Further control variables included: Age squared, number of children, married, willingness to take risks, local GDP per capita, educational degree dummies, time dummy for 2012 . The $F$-tests are for joint significance of the variables indicated; the selection variables are the local unemployment rate and the interaction terms involving the trade occupation dummies. Standard errors clustered at the person level in parentheses. ${ }^{*} /{ }^{* *} /{ }^{* *}$ : Significance at the $10 \% / 5 \% / 1 \%$ levels. Source: Own estimations based on the German Socio-economic Panel 2002, 2007, and 2012.

The marginal personal income tax rate has significant effects on the probabilities of holding two asset classes, business equity and rental property. Increasing the marginal tax rate by 10 percentage points increases the probability of holding assets in a private business by 1.2 percentage points. This corresponds to $14 \%$ of the average ownership probability of $8.4 \%$ indicated at the bottom of the table, so the effect is economically very significant. The positive effect of the marginal tax rate on business ownership is consistent with a tax avoidance or evasion motivation. Higher tax rates raise incentives to create a private business as a vehicle to shelter income. This finding is in line with the findings of Cullen and Gordon (2007) using U.S. tax return data. ${ }^{17}$

The second significant effect of the marginal tax rate is on property rented out, with the opposite sign. A hike in the marginal tax rate by 10 percentage points decreases the probability of holding rental property by 2.1 percentage

\footnotetext{
${ }^{16}$ The first stage of the IV regressions has the marginal tax rate as the dependent variable and is identical for all asset classes.

${ }^{17}$ These authors emphasize a particular tax avoidance mechanism available in the United States, i.e. the possibility to shift income between the tax bases for the personal and corporate income taxes.
} 
points, i.e. $12.6 \%$ of the average ownership probability of $16.5 \%$. The effects on the ownership probabilities of the other asset classes are small and insignificant. Together, the results indicate that tax-induced investment in an own business and in rental property are substitutes at the extensive margin.

Next, we consider the variables testing the effects of the change in the regulation of entry into entrepreneurship for trade and craft occupations in 2004. The interaction term of the dummy variable indicating A1 occupations with the post-reform time period dummy is positive and significant in the ownership equation of private business equity. This indicates that the probability of owning a business increased after the entry regulation reform for workers in A1 occupations. This is very plausible because the reform lowered the educational entry requirements for these occupations (see Section 4.2). This result confirms the finding of Rostam-Afschar (2014), though the interaction on B1 is not significantly positive as expected. The variables included in these first step selection equations, but excluded from the second step estimations of portfolio shares (i.e., the entry regulation reform dummies and the local unemployment rate) are jointly significant in the business equity ownership equation ( $p$-value: 0.0519$)$. This facilitates identification of the equation of the conditional portfolio share of business equity, which is of primary interest in this analysis. $^{18}$

Income and wealth have significant effects on the probability of owning most asset classes (see the $p$-values of the F-tests of joint significance of the linear and square terms at the bottom of the table). The probability of owning private business equity increases with gross (before-tax) income and personal net worth at decreasing marginal rates. (The turning points are beyond the ranges relevant in our data.) Similar income and wealth effects can be observed for rental property and life and private pension insurance. For owner occupied housing, only the wealth effect is significant, whereas for financial assets, only the income effect is significant. The finding that the wealth and income effects are initially positive or insignificant for all asset classes at the extensive margin is plausible. When individuals have higher income and larger amounts of wealth, they hold more diversified portfolios with a larger number of different asset classes (e.g., Carroll 2002).

\subsection{Intensive Margin}

Table 5 presents the results of the second step estimations of the portfolio shares of the six asset classes in the private wealth portfolio. The system of demand equations is estimated jointly using 3SLS in first differences, with an endogenous marginal tax rate and with selection correction. As outlined in Section 3, all transformed explanatory variables are treated as endogenous and appropriately instrumented. ${ }^{19}$

The strength of the instruments in the system of demand equations is tested using Shea's Partial $R^{2}$. The instruments are particularly strong in the equation of the portfolio share of private business equity (in the first column), which is of primary interest, with Shea's Partial $R^{2}=23.9 \%$. The statistic is smaller, but still satisfactory in the other

\footnotetext{
${ }^{18}$ The exclusion restrictions are jointly insignificant in the ownership equations of the other assets, although some of these variables are individually significant. It is plausible that regulation of entry into entrepreneurship and the local unemployment rate affect the probability of owning a business, but not necessarily ownership of other assets.

${ }^{19}$ In Table B.1 in Appendix B, we report standard errors robust to clustering at the person level. The clustered standard errors turn out to be mostly smaller than the regular standard errors in our 3SLS estimations. Therefore, to be conservative, we report regular standard errors in the other tables providing 3SLS results.
} 
equations, although quite small for tangible assets. ${ }^{20}$ The estimated coefficient of the selection term is significant in four out of the six equations including the equation of the portfolio share of private business equity. This indicates that it is important to account for selection into ownership of these assets. ${ }^{21}$

Table 5: Portfolio Shares of Asset Classes

\begin{tabular}{|c|c|c|c|c|c|c|}
\hline & Business equity & Owner Housing & Rental Prop. & Financials & Life Insurance & Tangible Assets \\
\hline \multirow[t]{2}{*}{ Marginal tax rate } & $-0.0708 * *$ & $0.0348 * * *$ & $-0.0753 * *$ & 0.0084 & $-0.0896 * *$ & -0.0533 \\
\hline & $(0.0296)$ & $(0.0130)$ & $(0.0313)$ & $(0.0750)$ & $(0.0350)$ & $(0.0449)$ \\
\hline \multirow[t]{2}{*}{ Gross income } & $0.1838 * * *$ & 0.0151 & 0.0081 & $-0.1314 * * *$ & 0.0214 & 0.0586 \\
\hline & $(0.0459)$ & $(0.0160)$ & $(0.0666)$ & $(0.0455)$ & $(0.0473)$ & $(0.0645)$ \\
\hline \multirow[t]{2}{*}{ Gross income sq. } & $-0.0111 * *$ & -0.0017 & -0.0025 & $0.0128 * * *$ & 0.0008 & 0.0003 \\
\hline & $(0.0055)$ & $(0.0031)$ & $(0.0095)$ & $(0.0047)$ & $(0.0054)$ & $(0.0185)$ \\
\hline \multirow{2}{*}{ Net worth } & 0.0790 & 0.0428 & 0.1067 & $-0.6237 * * *$ & 0.1251 & 0.3120 \\
\hline & $(0.0857)$ & $(0.0805)$ & $(0.1108)$ & $(0.1784)$ & $(0.1578)$ & $(0.2250)$ \\
\hline \multirow[t]{2}{*}{ Net worth sq. } & $-0.0294 *$ & 0.0041 & -0.0018 & $0.0585^{* *}$ & -0.0302 & -0.0663 \\
\hline & $(0.0165)$ & $(0.0212)$ & $(0.0291)$ & $(0.0243)$ & $(0.0242)$ & $(0.0689)$ \\
\hline \multirow[t]{2}{*}{ Selection term $(Z \hat{\gamma})^{2}-Z \hat{\gamma}$} & $-0.1540 *$ & 0.0076 & $-0.1107 *$ & -0.0358 & $-0.1554 * *$ & $0.1494 *$ \\
\hline & $(0.0793)$ & $(0.0208)$ & $(0.0583)$ & $(0.0773)$ & $(0.0651)$ & $(0.0846)$ \\
\hline Further controls & $\checkmark$ & $\checkmark$ & $\checkmark$ & $\checkmark$ & $\checkmark$ & $\checkmark$ \\
\hline First-differenced observations & 3,979 & 3,979 & 3,979 & 3,979 & 3,979 & 3,979 \\
\hline$F$-test income terms ( $p$-val.) & 0.0000 & 0.6183 & 0.9510 & 0.0145 & 0.2900 & 0.5194 \\
\hline$F$-test wealth terms ( $p$-val.) & 0.1427 & 0.6233 & 0.2611 & 0.0017 & 0.4445 & 0.3681 \\
\hline Angrist/Pischke Partial $R^{2}$ & 0.1924 & 0.0576 & 0.0327 & 0.0516 & 0.0727 & 0.0233 \\
\hline Shea's Partial $R^{2}$ & 0.2387 & 0.0572 & 0.0401 & 0.0522 & 0.0703 & 0.0250 \\
\hline Uncond. mean portfolio share & 0.0325 & 0.4132 & 0.0697 & 0.2039 & 0.2673 & 0.0135 \\
\hline Conditional mean portf. share & 0.3865 & 0.7636 & 0.4231 & 0.3437 & 0.3775 & 0.1577 \\
\hline
\end{tabular}

Note: System 3SLS estimation of asset class shares in first differences with endogenous tax rate and selection correction. The dependent variable is the share of the asset class indicated at the column head in the private wealth portfolio. The instrument for the actual marginal tax rate is the simulated marginal tax rate using exogenously updated individual income from 2002 and the contemporaneous tax code. Estimated in first differences to eliminate individual fixed effects. Gross income is in 10,000 Euro and net worth in 10 mill. Euro, both in prices of 2005. Further control variables included: Age squared, number of children, married, willingness to take risks, local GDP per capita, time dummy for 2012. All variables are transformed and instrumented as described in Section 3. Standard errors in parentheses. $*^{* *} /{ }^{* * *}$ : Significance at the 10\%/5\%/1\% levels. Source: Own estimations based on the German Socio-economic Panel 2002, 2007, and 2012 .

The estimated coefficient of the marginal personal income tax rate is significant for the portfolio share of private business equity, as in the ownership probability equation, but has the opposite sign. An increase in the marginal tax rate decreases the share of own business equity in the private wealth portfolio conditional on being a business owner. ${ }^{22}$ This is consistent with a disincentive effect of taxation on marginal investment in productive businesses. The negative effect of taxes on entrepreneurial activity is in line with Hansson (2012).

Our finding of opposite signs of tax effects at the extensive and intensive margins are inconsistent with the standard model of portfolio choice, but can be rationalised using our extended model that allows for tax sheltering. The

\footnotetext{
${ }^{20}$ A limitation of Shea's Partial $R^{2}$ is that it does not allow to formally test for weak instruments. Therefore, for each endogenous regressor, we also conduct Sanderson-Windmeijer's $\chi^{2}$ and $F$-test for underidentification and for weak identification. In both versions of the test as well as in a joint $F$-test (not reported in the table), no $p$-value exceeds the 5\% significance level, and we can infer that the hypotheses that the endogenous regressors are underidentified or weakly identified are rejected. The method by Sanderson and Windmeijer (2016) is a modification of the tests described by Angrist and Pischke (2009), which we report in the table.

${ }^{21}$ Note that our linear selection correction model allows interpreting the effect of an increase in the probability of being an entrepreneur $\left(Z_{i t} \gamma_{m}\right)$ more directly than other selection correction models (see equation A.1 in Appendix A.2). If a 10 percentage points larger share of the population engaged in entrepreneurship, the share invested in own business equity conditional on business ownership would be 1.5 percentage points lower.

${ }^{22}$ We discuss the effect size in Section 6.3.
} 
opposing effect of taxes on the probability of ownership and on the conditional portfolio share of the same asset type also indicates that a Tobit model is inappropriate for estimation of tax effects on household portfolio choice when business equity is included, because the Tobit model restricts the signs of the effects to be the same. As mentioned before, the Tobit model has frequently been used in the literature not considering business equity (Poterba and Samwick 2002; Alan et al. 2010).

Significant tax effects are also detected for owner-occupied housing, rental property, and life and private pension insurance policies. For owner-occupied housing, the coefficient of the marginal tax rate is positive and significant, which may indicate that business equity and owner-occupied housing are used as substitutes when tax rates change. The estimated tax effect on business equity is the most robust among the six asset classes. When instead of 3SLS we estimate inefficient 2SLS models equation by equation without taking into account correlation of the error terms across equations (Table B.2 in Appendix B), the coefficient of the marginal tax rate in the business equity equation becomes even more negative and remains statistically significant, but the coefficients of the marginal tax rate become statistically insignificant for the other asset classes. Therefore, our conclusions focus on the robustly estimated tax effects on private business equity.

Income effects are significant for the portfolio shares of business equity and financial assets (joint significance of the linear and square terms as indicated at the bottom of Table 5). When their income grows (starting from zero), private persons invest a larger share of their wealth in their own business, but a lower share in financial assets at the intensive margins. These effects attenuate when income increases further. The income effects occur holding net worth constant. Wealth effects are significant (joint tests of the linear and square terms) for financial assets, with an initially negative effect on the portfolio share of financial assets.

\subsection{Unconditional and Conditional Marginal Effects}

The average unconditional portfolio shares as well as the portfolio shares conditional on owning a positive amount of an asset class appear at the bottom of Table 5 (unweighted). Based on the estimated coefficients of the selection and portfolio share equations, we calculate the average unconditional and conditional marginal effects of the marginal personal income tax rate using the formulas derived in Appendix A.3. When the government increases the marginal tax rate by 10 percentage points, the portfolio share of private business equity conditional on owning a private business decreases by 0.891 percentage points. This is $2.3 \%$ of the unweighted average conditional portfolio share of private business equity in the sample of $38.7 \%$. The finding is consistent with a disincentive effect of the marginal tax rate on marginal investment conditional on being a business owner.

The signs of the unconditional effects depend on both the estimated selection and the portfolio share equations. Increasing the marginal tax rate by 10 percentage points increases the unconditional portfolio share of private business equity by 0.093 percentage points. This is $2.9 \%$ of the average unconditional portfolio share of private business equity in the sample of $3.25 \%$. Thus, the sign of the unconditional tax effect is the same as in the ownership selection equation, but opposite to the effect on the conditional portfolio share. This indicates that the tax effect at the extensive margin overcompensates the effect at the intensive margin. 


\section{Conclusion}

We have investigated the effects of the marginal personal income tax rate on household portfolios focusing on entrepreneurial business equity, which has been almost completely neglected in the extant empirical literature on tax effects on household portfolio choice. We extend the standard theoretical portfolio choice model by allowing for partial sheltering of income from an own business. This could be legal tax avoidance and/or illegal tax evasion. In contrast to the standard model, our model implies that tax effects could have different signs at the extensive margin (probability of being an entrepreneur, i.e., of holding own business equity) and intensive margin (portfolio share of private business equity conditional on being a business owner).

For our empirical analysis, we use representative panel data including private business equity and the other most important asset types of private persons in Germany. We estimate simultaneous demand equations for six asset classes, including private business equity, eliminate unobserved individual fixed effects, and identify tax effects through changes in the tax code over time. We also control for selection into entrepreneurship by exploiting a reform in entry regulation during our observation period.

Our empirical results indicate that lower marginal personal income tax rates decrease the probability of owning a business, but increase the conditional portfolio share that entrepreneurs invest in their own business. This is consistent with a tax avoidance or evasion motive for owning a marginal business, but a disincentive effect of higher marginal tax rates on marginal investment in productive businesses. Quantitatively, a decrease in the marginal tax rate by 10 percentage points increases the conditional portfolio share of private business equity by $2.3 \%$ of the average conditional portfolio share of $39 \%$, but decreases the unconditional portfolio share by $2.9 \%$ of the unconditional average of $3 \%$. The latter occurs due to a negative effect of a tax cut on the probability of being an entrepreneur. The opposing signs of the tax effects at the intensive and extensive margins are inconsistent with the standard portfolio choice model, but can be rationalized using our reformulated model allowing for tax sheltering of business income.

Our results contribute to reconciling the inconclusive results from the literature of tax effects on entrepreneurship. Our finding that lower marginal tax rates have a negative effect on the probability of being an entrepreneur is consistent with Cullen and Gordon (2007), who find that a uniform cut in personal tax rates would lead to a fall in the entrepreneurship rate in the United States. However, our finding that the conditional amount of own wealth that entrepreneurs put at risk in their business increases when tax rates are lower may explain why other studies find positive effects of tax cuts on entrepreneurship in other countries and situations, such as that by Hansson (2012) for Sweden.

In light of the mixed empirical results from the literature, our theoretical model, which receives support from our empirical results, offers some guidance for policymakers. By highlighting that lower taxes may drive out businesses that are viable only due to tax sheltering, but increase equity investment in private businesses that are also worthwhile in the absence of taxes, our analysis strengthens the case for lower tax rates to stimulate productive entrepreneurial risk taking. Future research should more specifically investigate the mechanisms to scrutinize this point. An important challenge for the future is to collect and analyse data on tax avoidance and evasion, which is of course notoriously difficult due to the very nature of income concealment. 


\section{References}

ACs, Z., AND D. AUdretsch (2005): “Entrepreneurship, Innovation and Technological Change," Foundations and Trends in Entrepreneurship, 1(4), 149-195.

Alan, S., K. Atalay, T. F. Crossley, and S.-H. Jeon (2010): "New Evidence on Taxes and Portfolio Choice," Journal of Public Economics, 94(11-12), 813-823.

Allingham, M. G., And A. SAndmo (1972): "Income Tax Evasion: A Theoretical Analysis," Journal of Public Economics, 1(3), 323-338.

ANGRIST, J. D., AND J.-S. PISChKe (2009): Mostly Harmless Econometrics: An Empiricist's Companion. Princeton University Press.

Auerbach, A. J., And M. A. King (1983): "Taxation, Portfolio Choice, and Debt-Equity Ratios: A General Equilibrium Model," Quarterly Journal of Economics, 98(4), 587-609.

BRUCE, D. (2000): "Effects of the United States Tax System on Transitions Into Self-Employment," Labour Economics, 7(5), 545-574.

BRUCE, D., ANd M. Mohsin (2006): “Tax Policy and Entrepreneurship: New Time Series Evidence,” Small Business Economics, 26(5), 409-425.

Caliendo, M., F. M. Fossen, and A. S. Kritikos (2009): "Risk Attitudes of Nascent Entrepreneurs-New Evidence from an Experimentally Validated Survey," Small Business Economics, 32(2), 153-167.

CARree, M. A., AND A. R. ThURIK (2003): The Impact of Entrepreneurship on Economic Growth 437-471. Springer US, Boston, MA.

Carroll, C. D. (2002): "Portfolios of the Rich," in Household Portfolios, ed. by L. Guiso, M. Haliassos, and T. Japelli, 389-430. MIT Press.

Cullen, J. B., And R. H. GoRdon (2007): “Taxes and Entrepreneurial Risk-Taking: Theory and Evidence for the U.S.," Journal of Public Economics, 91(7-8), 1479-1505.

DOMAR, E. D., AND R. A. MusgraVe (1944): “Proportional Income Taxation and Risk-Taking,” Quarterly Journal of Economics, 58(3), 388-422.

Evans, D. S., AND L. S. LeIghton (1989): "Some Empirical Aspects of Entrepreneurship,” American Economic Review, 79(3), 519-535.

FAIRLIE, R. W., AND F. M. FosSEn (2017): “Opportunity versus Necessity Entrepreneurship: Two Components of Business Creation,” Discussion Paper 17-014, Stanford Institute for Economic Policy Research.

Feldstein, M. (1976): "Personal Taxation and Portfolio Composition: An Econometric Analysis," Econometrica, 44(4), 631-650. 
Feldstein, M. S., And J. Slemrod (1980): "Personal Taxation, Portfolio Choice, and the Effect of the Corporation Income Tax," Journal of Political Economy, 88(5), 854-866.

Fossen, F. M. (2009): "Would a Flat-Rate Tax Stimulate Entrepreneurship in Germany? A Behavioural Microsimulation Analysis Allowing for Risk," Fiscal Studies, 30(2), 179-218.

(2011): "The Private Equity Premium Puzzle Revisited-New Evidence on the Role of Heterogeneous Risk Attitudes," Economica, 78(312), 656-675.

(2012): "Risk Attitudes and Private Business Equity," in The Oxford Handbook of Entrepreneurial Finance, ed. by D. Cumming, 109-132. Oxford University Press.

Fossen, F. M., And D. Rostam-Afschar (2013): "Precautionary and Entrepreneurial Savings: New Evidence from German Households," Oxford Bulletin of Economics and Statistics, 75(4), 528-555.

Fossen, F. M., And M. Simmler (2016): "Personal Taxation of Capital Income and the Financial Leverage of Firms," International Tax and Public Finance, 23(1), 48-81.

Fossen, F. M., And V. STEIneR (2009): “Income Taxes and Entrepreneurial Choice: Empirical Evidence from Two German Natural Experiments," Empirical Economics, 36(3), 487-513.

Gentry, W. M., And R. G. Hubbard (2000): “Tax Policy and Entrepreneurial Entry,” American Economic Review, 90(2), 283-287.

(2004): “Entrepreneurship and Household Saving,” Advances in Economic Analysis \& Policy, 4(1), $283-287$.

German Federal Statistical OfFice (2016): “Umsatzsteuerstatistik (Veranlagungen) 2012,” Fachserie 14, Reihe 8.2.

Gruber, J., AND E. SAEZ (2002): “The Elasticity of Taxable Income: Evidence and Implications,” Journal of Public Economics, 84(1), 1-32.

Hansson, Å. (2012): “Tax Policy and Entrepreneurship: Empirical Evidence from Sweden,” Small Business Economics, 38(4), 495-513.

Heckman, J. J. (1979): “Sample Selection Bias as a Specification Error,” Econometrica, 47(1), 153-161.

Hubbard, R. G. (1985): "Personal Taxation, Pension Wealth, and Portfolio Composition,” Review of Economics and Statistics, 67(1), 53-60.

Jessen, R., D. Rostam-Afschar, And V. Steiner (2017): “Getting the Poor to Work: Three Welfare Increasing Reforms for a Busy Germany," Public Finance Analysis, 73(1), 1-41.

KAnbur, S. (1981): “Risk Taking and Taxation,” Journal of Public Economics, 15(2), 163-184.

KIng, M. A., AND J. I. LEAPE (1998): “Wealth and Portfolio Composition: Theory and Evidence,” Journal of Public Economics, 69(2), 155-193. 
Konrad, K. A. (1991): “The Domar-Musgrave Phenomenon and Adverse Selection,” European Journal of Political Economy, 7(1), 41-53.

Lin, W.-Z., And C. YAng (2001): “A Dynamic Portfolio Choice Model of Tax Evasion: Comparative Statics of Tax Rates and its Implication for Economic Growth,” Journal of Economic Dynamics and Control, 25(11), 1827-1840.

Ochmann, R. (2014): “Differential Income Taxation and Household Asset Allocation,” Applied Economics, 46(8), 880-894.

Olsen, R. J. (1980): “A Least Squares Correction for Selectivity Bias,” Econometrica, 48(7), 1815-1820.

Poterba, J. (2002a): “Taxation and Portfolio Structure: Issues and Implications," in Household Portfolios, ed. by L. Guiso, M. Haliassos, and T. Japelli. MIT Press.

Poterba, J. M. (2002b): “Taxation, Risk-Taking, and Household Portfolio Behavior,” vol. 3 of Handbook of Public Economics, 1109-1171. Elsevier.

Poterba, J. M., And A. A. SAmwick (2002): “Taxation and Household Portfolio Composition: US Evidence from the 1980s and 1990s," Journal of Public Economics, 87(1), 5-38.

Rostam-Afschar, D. (2014): "Entry Regulation and Entrepreneurship: A Natural Experiment in German Craftsmanship," Empirical Economics, 47(3), 1067-1101.

SAMwICK, A. A. (2000): "Portfolio Responses to Taxation: Evidence from the End of the Rainbow," in Does Atlas Shrug? The Economic Consequences of Taxing the Rich, ed. by J. Slemrod. Harvard University Press.

SANDERSON, E., AND F. WindmeIJER (2016): "A Weak Instrument-Test in Linear IV Models with Multiple Endogenous Variables,” Journal of Econometrics, 190(2), 212-221.

SAndmo, A. (1977): "Portfolio Theory, Asset Demand and Taxation: Comparative Statics with Many Assets," Review of Economic Studies, 44(2), 369-379.

Shonkwiler, J. S., And S. T. Yen (1999): “Two-Step Estimation of a Censored System of Equations,” American Journal of Agricultural Economics, 81(4), 972-982.

Steiner, V., K. Wrohlich, P. HaAn, And J. Geyer (2012): “Documentation of the Tax-Benefit Microsimulation Model STSM: Version 2012,” Data Documentation 63, DIW Berlin, German Institute for Economic Research.

van PraAg, C. M., And P. H. Versloot (2007): “What is the Value of Entrepreneurship? A Review of Recent Research," Small Business Economics, 29(4), 351-382.

Wagner, G. G., J. R. Frick, And J. Schupp (2007): “The German Socio-Economic Panel Study (SOEP): Scope, Evolution and Enhancements," Journal of Applied Social Science Studies, 127(1), 139-169.

WEn, J.-F., And D. V. Gordon (2014): “An Empirical Model of Tax Convexity and Self-Employment,” The Review of Economics and Statistics, 96(3), 471-482.

Yitzhaki, S. (1974): “Income Tax Evasion: A Theoretical Analysis,” Journal of Public Economics, 3(2), 201-202. 


\section{Appendix A. Derivation of the Estimation Equations}

\section{Appendix A.1. Selection Correction}

Following Olsen (1980), equation (19) describes portfolio shares at the intensive margin, where equations (20) and (21) are the equations of selection into ownership of a particular asset. To avoid clutter, we suppress the time and asset class indices in this subsection. Assume $X_{i}$ and $Z_{i}$ are row vectors which conform to the column vectors of unknown coefficients $\beta$ and $\gamma$, respectively. The $X$ 's and $Z$ 's are exogenous.

Assume that the expected value of the error of the intensive regression is zero, $E\left(u_{i}\right)=0$, its variance is $E\left(u_{i} u_{j}\right)=$ $\sigma_{u}^{2}$ for $i=j$, and it is homoskedastic $\left(E\left(u_{i} u_{j}\right)=0\right.$ for $\left.i \neq j\right)$. The expected value of the selection threshold is equal to $E\left(v_{i}\right)=\mu_{v}$, its variance is $E\left[\left(v_{i}-\mu_{v}\right)\left(v_{i}-\mu_{v}\right)\right]=\sigma_{v}^{2}$ for $i=j$, and it is homoskedastic $\left(E\left[\left(v_{i}-\mu_{v}\right)\left(v_{i}-\mu_{v}\right)\right]=\right.$ 0 for $i \neq j)$. The covariance between the error of the intensive regression and the selection threshold is $\operatorname{Cov}\left(u_{i}, v_{i}\right)=$ $E\left(u_{i} v_{i}\right)-E\left(u_{i}\right) E\left(v_{i}\right)=\rho \sigma_{v} \sigma_{u}$ for $i=j$, and the error does not vary with the selection threshold of other individuals, i.e. $\operatorname{Cov}\left(u_{i}, v_{i}\right)=0$ for $i \neq j$.

Then the expected value of the error of the intensive regression conditional on the value of the selection threshold is

$$
E\left(u_{i} \mid v_{i}\right)=\rho\left(v_{i}-\mu_{v}\right) \sigma_{u} / \sigma_{v}
$$

By assuming the conditional expectation of $u_{i}$ given $v_{i}$ is linear in $v_{i}$ we can use the decomposition

$$
u_{i}=\rho\left(v_{i}-\mu_{v}\right) \sigma_{u} / \sigma_{v}+\varepsilon_{i}
$$

where $\varepsilon_{i}$ and $v_{i}$ are uncorrelated. Substituting this into $y_{i}=X_{i} \beta+u_{i}$ gives

$$
y_{i}=X_{i} \beta+\rho\left(v_{i}-\mu_{v}\right) \sigma_{u} / \sigma_{v}+\varepsilon_{i}
$$

Then the conditional mean is

$$
E\left(y_{i} \mid X_{i}, v_{i}<Z_{i} \gamma\right)=X_{i} \beta+\rho \sigma_{u} E\left(v_{i} \mid v_{i}<Z_{i} \gamma\right) / \sigma_{v}-\rho \sigma_{u} \mu_{v} / \sigma_{v}
$$

If $v_{i}$ is a standard normally distributed random variable with mean $\mu_{v}=0$ and variance $\sigma_{v}^{2}=1$, then it follows that

$$
E\left(v_{i} \mid v_{i}<Z_{i} \gamma\right)=-\frac{\phi\left(Z_{i} \gamma\right)}{\Phi\left(Z_{i} \gamma\right)} \text { (Inverse Mills Ratio) }
$$

and the estimation equation is:

$$
E\left(y_{i} \mid X_{i}, v_{i}<Z_{i} \gamma\right)=X_{i} \beta-\underbrace{\rho \sigma_{u}}_{\delta} \frac{\phi\left(Z_{i} \gamma\right)}{\Phi\left(Z_{i} \gamma\right)},
$$

where $\delta$ and $\beta$ are the parameters to be estimated.

If $v_{i}$ is instead uniformly distributed over the interval $[0,1]$, it follows that $E\left(v_{i}\right)=\mu_{v}=1 / 2$, and $V\left(v_{i}\right)=1 / 12$, so $\sigma_{v}=\frac{1}{2 \sqrt{3}}$. Using the equation for the conditional mean as above with these values gives

$$
\begin{gathered}
E\left(y_{i} \mid X_{i}, v_{i}<Z_{i} \gamma\right)=X_{i} \beta+\rho \sigma_{u} E\left(v_{i} \mid v_{i}<Z_{i} \gamma\right) / \sigma_{v}-\rho \sigma_{u} \mu_{v} / \sigma_{v} \\
=X_{i} \beta+\frac{\rho \sigma_{u} E\left(v_{i} \mid v_{i}<Z_{i} \gamma\right)}{\frac{1}{2 \sqrt{3}}}-\frac{\rho \sigma_{u} 1 / 2}{\frac{1}{2 \sqrt{3}}}
\end{gathered}
$$


Recognizing that $E\left(v_{i} \mid v_{i}<Z_{i} \gamma\right)=Z_{i} \gamma E\left(v_{i}\right)=Z_{i} \gamma 1 / 2$ gives

$$
\begin{gathered}
E\left(y_{i} \mid X_{i}, v_{i}<Z_{i} \gamma\right)=X_{i} \beta+\frac{\rho \sigma_{u} Z_{i} \gamma 1 / 2}{\frac{1}{2 \sqrt{3}}}-\frac{\rho \sigma_{u}}{\frac{1}{\sqrt{3}}} \\
=X_{i} \beta+\rho \sigma_{u} \sqrt{3}\left(Z_{i} \gamma-1\right) .
\end{gathered}
$$

From this follows

$$
E\left(y_{i} \mid X_{i}, v_{i}<Z_{i} \gamma\right)=X_{i} \beta+\underbrace{\rho \sigma_{u} \sqrt{3}}_{\delta}\left(Z_{i} \gamma-1\right) .
$$

Appendix A.2. System Estimation

Based on the assumption of a normally distributed error term in the selection equation, Shonkwiler and Yen (1999) show that the conditional mean of $y_{m i}$ for individual $i$ in equation $m=1, \ldots, M$ is

$$
E\left(y_{m i} \mid X_{m i}, v_{m}<Z_{m i} \gamma_{m}\right)=f\left(X_{m i}, \beta_{m}\right)+\delta_{m} \frac{\phi\left(Z_{m i} \gamma_{m}\right)}{\Phi\left(Z_{m i} \gamma_{m}\right)} .
$$

Because $E\left(y_{m i} \mid X_{m i}, v_{m} \geq Z_{m i} \gamma_{m}\right)=0$, the unconditional mean of $y_{m i}$ for the $m$ th equation is

$$
E\left(y_{m i} \mid X_{m i}\right)=\Phi\left(Z_{m i} \gamma_{m}\right) f\left(X_{m i}, \beta_{m}\right)+\delta_{m} \phi\left(Z_{m i} \gamma_{m}\right)
$$

In our case, we have analogously for the uniform distribution

$$
E\left(y_{m i} \mid X_{m i}, v_{m}<Z_{m i} \gamma_{m}\right)=f\left(X_{m i}, \beta_{m}\right)+\delta_{m}\left(Z_{m i} \gamma_{m}-1\right)
$$

and

$$
E\left(y_{m i} \mid X_{m i}\right)=Z_{m i} \gamma_{m} f\left(X_{m i}, \beta_{m}\right)+\delta_{m}\left(\left(Z_{m i} \gamma_{m}\right)^{2}-Z_{m i} \gamma_{m}\right)
$$

\section{Appendix A.3. Marginal Effects}

Under assumption of uniformly distributed $v_{i}$ over $[0,1]$, the marginal effects for a variable $x_{m i}$ if $x_{m i} \in Z_{m i}$ and $x_{m i} \in X_{m i}$ conditional on selection are

$$
\frac{\partial E\left(y_{m i} \mid X_{m i}, v_{m}<Z_{m i} \gamma_{m}\right)}{\partial x_{m i k}}=\beta_{m k} f^{\prime}\left(X_{m i}, \beta_{m}\right)+\delta_{m} \gamma_{m k}
$$

and the unconditional marginal effects are

$$
\frac{\partial E\left(y_{m i} \mid X_{m i}\right)}{\partial x_{m i k}}=\gamma_{m k} f\left(X_{m i}, \beta_{m}\right)+Z_{m i} \gamma_{m} \beta_{m k} f^{\prime}\left(X_{m i}, \beta_{m}\right)+\delta_{m} \gamma_{m k} 2 Z_{m i} \gamma_{m}-\delta_{m} \gamma_{m k}
$$




\section{Appendix B. Supplementary Tables}

Table B.1: Portfolio Shares of Asset Classes (with Cluster Robust Standard Errors)

\begin{tabular}{lrrrrrr}
\hline & Business equity & Owner Housing & Rental Prop. & Financials & Life Insurance & Tangible Assets \\
\hline Marginal tax rate & $-0.0708^{* *}$ & $0.0348^{* * *}$ & $-0.0753^{* * *}$ & 0.0084 & $-0.0896^{* * *}$ & $-0.0533^{*}$ \\
& $(0.0288)$ & $(0.0126)$ & $(0.0257)$ & $(0.0667)$ & $(0.0320)$ & $(0.0316)$ \\
Gross income & $0.1838^{* * *}$ & 0.0151 & 0.0081 & $-0.1314^{* * *}$ & 0.0214 & 0.0586 \\
& $(0.0625)$ & $(0.0130)$ & $(0.0659)$ & $(0.0383)$ & $(0.0297)$ & $(0.0423)$ \\
Gross income sq. & -0.0111 & -0.0017 & -0.0025 & $0.0128^{* * *}$ & 0.0008 & 0.0003 \\
& $(0.0069)$ & $(0.0024)$ & $(0.0111)$ & $(0.0036)$ & $(0.0031)$ & $(0.0086)$ \\
Net worth & 0.0790 & 0.0428 & 0.1067 & $-0.6237 * *$ & $0.1251^{*}$ & $0.3120^{*}$ \\
& $(0.2122)$ & $(0.0586)$ & $(0.1310)$ & $(0.2465)$ & $(0.0721)$ & $(0.1759)$ \\
Net worth sq. & -0.0294 & 0.0041 & -0.0018 & $0.0585 * *$ & $-0.0302^{* * *}$ & $-0.0663^{*}$ \\
& $(0.0281)$ & $(0.0126)$ & $(0.0351)$ & $(0.0247)$ & $(0.0090)$ & $(0.0352)$ \\
Selection term & $-0.1540^{*}$ & 0.0076 & $-0.1107 * * *$ & -0.0358 & $-0.1554^{* * *}$ & $0.1494^{* *}$ \\
& $(0.0809)$ & $(0.0185)$ & $(0.0374)$ & $(0.0555)$ & $(0.0488)$ & $(0.0719)$ \\
Further controls & $\checkmark$ & $\checkmark$ & & $\checkmark$ & $\checkmark$ & $\checkmark$ \\
First-differenced observations & 3,979 & 3,979 & 3,979 & 3,979 & 3,979 & 3,979 \\
F-test income terms $(p$-val.) & 0.0012 & 0.4508 & 0.9686 & 0.0017 & 0.0002 & 0.2194 \\
F-test wealth terms $p$-val.) & 0.2097 & 0.3723 & 0.431 & 0.0353 & 0.0001 & 0.156 \\
Angrist/Pischke Partial $R^{2}$ & 0.1924 & 0.0576 & 0.0327 & 0.0516 & 0.0727 & 0.0233 \\
Shea's Partial $R^{2}$ & 0.2387 & 0.0572 & 0.0401 & 0.0522 & 0.0703 & 0.0250 \\
Uncond. mean portfolio share & 0.0325 & 0.4132 & 0.0697 & 0.2039 & 0.2673 & 0.0135 \\
Conditional mean portf. share & 0.3865 & 0.7636 & 0.4231 & 0.3437 & 0.3775 & 0.1577 \\
\hline
\end{tabular}

Note: System 3SLS estimation of asset class shares in first differences with endogenous tax rate and selection correction. The dependent variable is the share of the asset class indicated at the column head in the private wealth portfolio. The instrument for the actual marginal tax rate is the simulated marginal tax rate using exogenously updated individual income from 2002 and the contemporaneous tax code. Estimated in first differences to eliminate individual fixed effects. Gross income is in 10,000 Euro and net worth in 10 mill. Euro, both in prices of 2005. Further control variables included: Age squared, number of children, married, willingness to take risks, local GDP per capita, time dummy for 2012. All variables are transformed and instrumented as described in Section 3. Standard errors clustered at the person level in parentheses. */**/**: Significance at the $10 \% / 5 \% / 1 \%$ levels. Source: Own estimations based on the German Socio-economic Panel 2002, 2007, and 2012. 
Table B.2: Portfolio Shares of Asset Classes (Equation-by-Equation 2SLS Estimation)

\begin{tabular}{lrrrrrr}
\hline & Business equity & Owner Housing & Rental Prop. & Financials & Life Insurance & Tangible Assets \\
\hline Marginal tax rate & $-0.1840^{* *}$ & -0.0406 & 0.3542 & 0.3499 & 0.1390 & 0.0152 \\
& $(0.0787)$ & $(0.0760)$ & $(0.2537)$ & $(0.6948)$ & $(0.2031)$ & $(0.3043)$ \\
Gross income & $0.2163 * * *$ & 0.0260 & 0.0717 & -0.1281 & $-0.3646^{*}$ & -0.0292 \\
& $(0.0634)$ & $(0.0327)$ & $(0.1069)$ & $(0.1917)$ & $(0.2204)$ & $(0.2523)$ \\
Gross income sq. & $-0.0132^{*}$ & -0.0001 & -0.0025 & 0.0138 & 0.0395 & 0.1032 \\
& $(0.0070)$ & $(0.0048)$ & $(0.0132)$ & $(0.0156)$ & $(0.0241)$ & $(0.1592)$ \\
Net worth & $0.3402^{* * *}$ & 0.1226 & -0.4594 & -0.2701 & 0.0608 & 0.9556 \\
& $(0.1179)$ & $(0.2280)$ & $(0.4882)$ & $(0.3185)$ & $(0.3679)$ & $(1.1630)$ \\
Net worth sq. & $-0.0624 * * *$ & -0.0183 & 0.0468 & 0.0181 & -0.0412 & -0.4357 \\
& $(0.0203)$ & $(0.0410)$ & $(0.0697)$ & $(0.0406)$ & $(0.0380)$ & $(0.5709)$ \\
Selection term & $-0.7080^{* * *}$ & -0.1244 & 0.6366 & -0.0653 & 0.3119 & -0.0661 \\
& $(0.1574)$ & $(0.1213)$ & $(0.4976)$ & $(0.4266)$ & $(0.5991)$ & $(0.3023)$ \\
Further controls & $\checkmark$ & $\checkmark$ & $\checkmark$ & $\checkmark$ & $\checkmark$ & $\checkmark$ \\
First-differenced observations & 3,979 & 3,979 & 3,979 & 3,979 & 3,979 & 3,979 \\
$F$-test income terms $(p$-val.) & 0.0004 & 0.8624 & 0.2400 & 0.8460 & 0.3629 & 0.6429 \\
$F$-test net worth terms $(p$-val.) & 0.0001 & 0.4544 & 0.6142 & 0.3470 & 0.2546 & 0.3012 \\
Angrist/Pischke Partial $R^{2}$ & 0.1924 & 0.0576 & 0.0327 & 0.0516 & 0.0727 & 0.0233 \\
Shea's Partial $R^{2}$ & 0.2387 & 0.0572 & 0.0401 & 0.0522 & 0.0703 & 0.0250 \\
Uncond. mean portfolio share & 0.0325 & 0.4132 & 0.0697 & 0.2039 & 0.2673 & 0.0135 \\
Conditional mean portf. share & 0.3865 & 0.7636 & 0.4231 & 0.3437 & 0.3775 & 0.1577 \\
\hline
\end{tabular}

Note: Equation-by-equation 2SLS estimation of asset class shares in first differences with endogenous tax rate and selection correction. The dependent variable is the share of the asset class indicated at the column head in the private wealth portfolio. The instrument for the actual marginal tax rate is the simulated marginal tax rate using exogenously updated individual income from 2002 and the contemporaneous tax code. Estimated in first differences to eliminate individual fixed effects. Gross income is in 10,000 Euro and net worth in 10 mill. Euro, both in prices of 2005. Further control variables included: Age squared, number of children, married, willingness to take risks, local GDP per capita, time dummy for 2012. All variables are transformed and instrumented as described in Section 3. Standard errors in parentheses. ${ }^{* * *} /{ }^{* *}$ : Significance at the $10 \% / 5 \% / 1 \%$ levels. Source: Own estimations based on the German Socio-economic Panel 2002, 2007, and 2012. 


\section{Hohenheim Discussion Papers in Business, Economics and Social Sciences}

The Faculty of Business, Economics and Social Sciences continues since 2015 the established "FZID Discussion Paper Series" of the "Centre for Research on Innovation and Services (FZID)" under the name "Hohenheim Discussion Papers in Business, Economics and Social Sciences".

\section{Institutes}

$510 \quad$ Institute of Financial Management

520 Institute of Economics

530 Institute of Health Care \& Public Management

540 Institute of Communication Science

550 Institute of Law and Social Sciences

560 Institute of Economic and Business Education

570 Institute of Marketing \& Management

580 Institute of Interorganisational Management \& Performance

\section{Research Areas (since 2017)}

INEPA "Inequality and Economic Policy Analysis"

TKID "Transformation der Kommunikation - Integration und Desintegration"

NegoTrans "Negotiation Research - Transformation, Technology, Media and Costs"

INEF "Innovation, Entrepreneurship and Finance"

Download Hohenheim Discussion Papers in Business, Economics and Social Sciences from our homepage: https://wiso.uni-hohenheim.de/papers

\section{No. Author \\ 01-2015 Thomas Beissinger, Philipp Baudy}

02-2015 Fabian Wahl

03-2015 Tommaso Proietti, Martyna Marczak, Gianluigi Mazzi

04-2015 Thomas Beissinger, Nathalie Chusseau, Joël Hellier

05-2015 Matthias Mueller, Kristina Bogner, Tobias Buchmann, Muhamed Kudic

06-2015 Martyna Marczak, Thomas Beissinger

07-2015 Peng Nie, Galit Nimrod, Alfonso Sousa-Poza
Title Inst

THE IMPACT OF TEMPORARY AGENCY WORK 520 ON TRADE UNION WAGE SETTING:

A Theoretical Analysis

PARTICIPATIVE POLITICAL INSTITUTIONS AND CITY DEVELOPMENT 800-1800

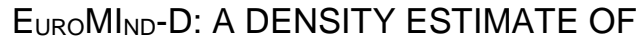
MONTHLY GROSS DOMESTIC PRODUCT FOR THE EURO AREA

OFFSHORING AND LABOUR MARKET REFORMS: MODELLING THE GERMAN EXPERIENCE

SIMULATING KNOWLEDGE DIFFUSION IN FOUR 520 STRUCTURALLY DISTINCT NETWORKS - AN AGENT-BASED SIMULATION MODEL

BIDIRECTIONAL RELATIONSHIP BETWEEN 520 INVESTOR SENTIMENT AND EXCESS RETURNS: NEW EVIDENCE FROM THE WAVELET PERSPECTIVE

INTERNET USE AND SUBJECTIVE WELL-BEING IN CHINA 
No. Author

Title

Inst

08-2015 Fabian Wahl

09-2015 Peng Nie, Alfonso Sousa-Poza

10-2015 Kristina Bogner

11-2015 Bogang Jun, Tai-Yoo Kim

12-2015 Volker Grossmann Aderonke Osikominu Marius Osterfeld

13-2015 Martyna Marczak Tommaso Proietti Stefano Grassi

14-2015 Carolina Castagnetti Luisa Rosti Marina Töpfer

15-2015 Alexander Opitz

01-2016 Michael Ahlheim, Jan Neidhardt

02-2016 Bogang Jun, Alexander Gerybadze, Tai-Yoo Kim

03-2016 Peng Nie, Alfonso Sousa-Poza

04-2016 Peter Spahn

05-2016 Vincent Dekker, Kristina Strohmaier, Nicole Bosch

06-2016 Philipp Baudy, Dario Cords
THE LONG SHADOW OF HISTORY

ROMAN LEGACY AND ECONOMIC DEVELOPMENT

520

- EVIDENCE FROM THE GERMAN LIMES

COMMUTE TIME AND SUBJECTIVE WELL-BEING IN URBAN CHINA

530

THE EFFECT OF PROJECT FUNDING ON INNOVATIVE PERFORMANCE AN AGENT-BASED SIMULATION MODEL

520

A NEO-SCHUMPETERIAN PERSPECTIVE ON THE ANALYTICAL MACROECONOMIC FRAMEWORK: THE EXPANDED REPRODUCTION SYSTEM

ARE SOCIOCULTURAL FACTORS IMPORTANT FOR STUDYING A SCIENCE UNIVERSITY MAJOR?

520

A DATA-CLEANING AUGMENTED KALMAN FILTER FOR ROBUST ESTIMATION OF STATE SPACE MODELS

520

THE REVERSAL OF THE GENDER PAY GAP AMONG PUBLIC-CONTEST SELECTED YOUNG EMPLOYEES

520

DEMOCRATIC PROSPECTS IN IMPERIAL RUSSIA: THE REVOLUTION OF 1905 AND THE POLITICAL STOCK MARKET

NON-TRADING BEHAVIOUR IN CHOICE EXPERIMENTS

THE LEGACY OF FRIEDRICH LIST: THE EXPANSIVE REPRODUCTION SYSTEM AND THE KOREAN HISTORY OF INDUSTRIALIZATION

FOOD INSECURITY AMONG OLDER EUROPEANS: 530 EVIDENCE FROM THE SURVEY OF HEALTH, AGEING, AND RETIREMENT IN EUROPE

POPULATION GROWTH, SAVING, INTEREST RATES AND STAGNATION. DISCUSSING THE EGGERTSSONMEHROTRA-MODEL

A DATA-DRIVEN PROCEDURE TO DETERMINE THE BUNCHING WINDOW - AN APPLICATION TO THE NETHERLANDS

DEREGULATION OF TEMPORARY AGENCY EMPLOYMENT IN A UNIONIZED ECONOMY: DOES THIS REALLY LEAD TO A SUBSTITUTION OF REGULAR EMPLOYMENT? 
No.

07-2016

Robin Jessen, Davud Rostam-Afschar, Sebastian Schmitz

08-2016 Peng Nie, Alfonso Sousa-Poza, Jianhong Xue

09-2016 Bogang Jun, Seung Kyu-Yi, Tobias Buchmann, Matthias Müller

10-2016 Vladan Ivanovic, Vadim Kufenko, Boris Begovic Nenad Stanisic, Vincent Geloso

11-2016 David E. Bloom Michael Kuhn Klaus Prettner

12-2016 Franz X. Hof Klaus Prettner

13-2016 Jung-In Yeon Andreas Pyka Tai-Yoo Kim

14-2016 Benjamin Fuchs

15-2016 Seung-Kyu Yi Bogang Jun

16-2016 Gregor Pfeifer Fabian Wahl Martyna Marczak

17-2016 Malte Klein Andreas Sauer

18-2016 Klaus Prettner

19-2016 Klaus Prettner Andreas Schaefer

20-2016 Vadim Kufenko Klaus Prettner
Title

Inst

HOW IMPORTANT IS PRECAUTIONARY LABOR

520 SUPPLY?

FUEL FOR LIFE: DOMESTIC COOKING FUELS AND 530 WOMEN'S HEALTH IN RURAL CHINA

THE CO-EVOLUTION OF INNOVATION NETWORKS: 520 COLLABORATION BETWEEN WEST AND EAST GERMANY FROM 1972 TO 2014

CONTINUITY UNDER A DIFFERENT NAME. 520 THE OUTCOME OF PRIVATISATION IN SERBIA

THE CONTRIBUTION OF FEMALE HEALTH TO ECONOMIC DEVELOPMENT GROWTH

STRUCTURAL SHIFT AND INCREASING VARIETY IN KOREA, 1960-2010: EMPIRICAL EVIDENCE OF THE ECONOMIC DEVELOPMENT MODEL BY THE CREATION OF NEW SECTORS

THE EFFECT OF TEENAGE EMPLOYMENT ON CHARACTER SKILLS, EXPECTATIONS AND OCCUPATIONAL CHOICE STRATEGIES

HAS THE GERMAN REUNIFICATION 520 STRENGTHENED GERMANY'S NATIONAL INNOVATION SYSTEM? TRIPLE HELIX DYNAMICS OF GERMANY'S INNOVATION SYSTEM

ILLUMINATING THE WORLD CUP EFFECT: NIGHT LIGHTS EVIDENCE FROM SOUTH AFRICA

CELEBRATING 30 YEARS OF INNOVATION 570 SYSTEM RESEARCH: WHAT YOU NEED TO KNOW ABOUT INNOVATION SYSTEMS

THE IMPLICATIONS OF AUTOMATION FOR ECONOMIC GROWTH AND THE LABOR SHARE

HIGHER EDUCATION AND THE FALL AND RISE OF INEQUALITY

520

YOU CAN'T ALWAYS GET WHAT YOU WANT? 520 ESTIMATOR CHOICE AND THE SPEED OF CONVERGENCE 
No.

\section{Author} Alberto Bucci Klaus Prettner

02-2017 Julius Tennert Marie Lambert Hans-Peter Burghof

03-2017 Michael Ahlheim Oliver Frör Nguyen Minh Duc Antonia Rehl Ute Siepmann Pham Van Dinh

04-2017 Bohdan Kukharskyy Sebastian Seiffert

05-2017 Ana Abeliansky Klaus Prettner

06-2017 Vincent Geloso Vadim Kufenko

07-2017 Emanuel Gasteiger Klaus Prettner

08-2017 Klaus Prettner Holger Strulik

09-2017 David E. Bloom Simiao Chen Michael Kuhn Mark E. McGovern Les Oxley Klaus Prettner

10-2017 Sebastian Till Braun Nadja Dwenger

11-2017 Vadim Kufenko Klaus Prettner Vincent Geloso

12-2017 Frank M. Fossen Ray Rees Davud Rostam-Afschar Viktor Steiner
Title

CHILDRENS HEALTH, HUMAN CAPITAL ACCUMULATION, AND R\&D-BASED ECONOMIC

Inst

INEPA GROWTH

MORAL HAZARD IN VC-FINANCE: MORE

INEF EXPENSIVE THAN YOU THOUGHT

LABOUR AS A UTILITY MEASURE RECONSIDERED 520

GUN VIOLENCE IN THE U.S.: CORRELATES AND 520 CAUSES

AUTOMATION AND DEMOGRAPHIC CHANGE

INEQUALITY AND GUARD LABOR, OR

INEPA

PROHIBITION AND GUARD LABOR?

ON THE POSSIBILITY OF AUTOMATION-INDUCED STAGNATION

520

THE LOST RACE AGAINST THE MACHINE:

INEPA AUTOMATION, EDUCATION, AND INEQUALITY IN AN R\&D-BASED GROWTH MODEL

THE ECONOMIC BURDEN OF CHRONIC 520 DISEASES: ESTIMATES AND PROJECTIONS FOR CHINA, JAPAN, AND SOUTH KOREA

THE LOCAL ENVIRONMENT SHAPES REFUGEE INTEGRATION: EVIDENCE FROM POST-WAR GERMANY

DIVERGENCE, CONVERGENCE, AND THE HISTORY-AUGMENTED SOLOW MODEL

INEPA

HOW DO ENTREPRENEURIAL PORTFOLIOS

INEPA RESPOND TO INCOME TAXATION? 
(published 2009-2014)

\section{Competence Centers}

IK Innovation and Knowledge

ICT Information Systems and Communication Systems

CRFM Corporate Finance and Risk Management

$\mathrm{HCM} \quad$ Health Care Management

CM Communication Management

MM Marketing Management

ECO Economics

Download FZID Discussion Papers from our homepage: https://wiso.uni-hohenheim.de/archiv_fzid_papers

\begin{tabular}{|c|c|c|c|}
\hline Nr. & Autor & Titel & CC \\
\hline 01-2009 & Julian P. Christ & $\begin{array}{l}\text { NEW ECONOMIC GEOGRAPHY RELOADED: } \\
\text { Localized Knowledge Spillovers and the Geography of Innovation }\end{array}$ & IK \\
\hline 02-2009 & André P. Slowak & $\begin{array}{l}\text { MARKET FIELD STRUCTURE \& DYNAMICS IN INDUSTRIAL } \\
\text { AUTOMATION }\end{array}$ & IK \\
\hline 03-2009 & $\begin{array}{l}\text { Pier Paolo Saviotti, } \\
\text { Andreas Pyka }\end{array}$ & $\begin{array}{l}\text { GENERALIZED BARRIERS TO ENTRY AND ECONOMIC } \\
\text { DEVELOPMENT }\end{array}$ & IK \\
\hline 04-2009 & $\begin{array}{l}\text { Uwe Focht, Andreas } \\
\text { Richter and Jörg } \\
\text { Schiller }\end{array}$ & INTERMEDIATION AND MATCHING IN INSURANCE MARKETS & $\mathrm{HCM}$ \\
\hline 05-2009 & $\begin{array}{l}\text { Julian P. Christ, } \\
\text { André P. Slowak }\end{array}$ & $\begin{array}{l}\text { WHY BLU-RAY VS. HD-DVD IS NOT VHS VS. BETAMAX: } \\
\text { THE CO-EVOLUTION OF STANDARD-SETTING CONSORTIA }\end{array}$ & $\mathrm{IK}$ \\
\hline 06-2009 & $\begin{array}{l}\text { Gabriel Felbermayr, } \\
\text { Mario Larch and } \\
\text { Wolfgang Lechthaler }\end{array}$ & UNEMPLOYMENT IN AN INTERDEPENDENT WORLD & $\mathrm{ECO}$ \\
\hline 07-2009 & Steffen Otterbach & $\begin{array}{l}\text { MISMATCHES BETWEEN ACTUAL AND PREFERRED WORK } \\
\text { TIME: Empirical Evidence of Hours Constraints in } 21 \text { Countries }\end{array}$ & $\mathrm{HCM}$ \\
\hline 08-2009 & Sven Wydra & $\begin{array}{l}\text { PRODUCTION AND EMPLOYMENT IMPACTS OF NEW } \\
\text { TECHNOLOGIES - ANALYSIS FOR BIOTECHNOLOGY }\end{array}$ & IK \\
\hline 09-2009 & $\begin{array}{l}\text { Ralf Richter, } \\
\text { Jochen Streb }\end{array}$ & $\begin{array}{l}\text { CATCHING-UP AND FALLING BEHIND } \\
\text { KNOWLEDGE SPILLOVER FROM AMERICAN } \\
\text { TO GERMAN MACHINE TOOL MAKERS }\end{array}$ & IK \\
\hline
\end{tabular}


Nr.

Autor

Titel

CC

KYOTO AND THE CARBON CONTENT OF TRADE

ECO

Gabriel Felbermayr

11-2010 David E. Bloom,

ECONOMIC CONSEQUENCES OF LOW FERTILITY IN EUROPE

$\mathrm{HCM}$

Alfonso Sousa-Poza

12-2010 Michael Ahlheim, Oliver Frör

DRINKING AND PROTECTING - A MARKET APPROACH TO THE PRESERVATION OF CORK OAK LANDSCAPES

ECO

LABOUR AS A UTILITY MEASURE IN CONTINGENT VALUATION STUDIES - HOW GOOD IS IT REALLY?

ECO

Oliver Frör,

Antonia Heinke,

Nguyen Minh Duc,

and Pham Van Dinh

14-2010 Julian P. Christ

THE GEOGRAPHY AND CO-LOCATION OF EUROPEAN

IK

TECHNOLOGY-SPECIFIC CO-INVENTORSHIP NETWORKS

15-2010 Harald Degner

WINDOWS OF TECHNOLOGICAL OPPORTUNITY

DO TECHNOLOGICAL BOOMS INFLUENCE THE RELATIONSHIP BETWEEN FIRM SIZE AND INNOVATIVENESS?

16-2010 Tobias A. Jopp

THE WELFARE STATE EVOLVES:

GERMAN KNAPPSCHAFTEN, 1854-1923

$\mathrm{HCM}$

17-2010 Stefan Kirn (Ed.)

PROCESS OF CHANGE IN ORGANISATIONS THROUGH

ICT

eHEALTH

18-2010 Jörg Schiller

ÖKONOMISCHE ASPEKTE DER ENTLOHNUNG

$\mathrm{HCM}$

UND REGULIERUNG UNABHÄNGIGER

VERSICHERUNGSVERMITTLER

19-2010 Frauke Lammers,

CONTRACT DESIGN AND INSURANCE FRAUD: AN

$\mathrm{HCM}$

Jörg Schiller

EXPERIMENTAL INVESTIGATION

REAL WAGES AND THE BUSINESS CYCLE IN GERMANY

ECO

Thomas Beissinger

21-2010 Harald Degner,

Jochen Streb

FOREIGN PATENTING IN GERMANY, 1877-1932

IK

DOES DOWNWARD NOMINAL WAGE RIGIDITY

DAMPEN WAGE INCREASES?

ECO

Thomas Beissinger

23-2010 Mark Spoerer,

GUNS AND BUTTER - BUT NO MARGARINE: THE IMPACT OF Jochen Streb

NAZI ECONOMIC POLICIES ON GERMAN FOOD

ECO CONSUMPTION, 1933-38 
Nr.

Autor

Titel

24-2011 Dhammika Dharmapala, Nadine Riedel

25-2011 Michael Schuele, Stefan Kirn

26-2011 Marcus Müller, Guillaume Stern, Ansger Jacob and Stefan Kirn

27-2011 Monnet Benoit, Patrick Gbakoua and Alfonso Sousa-Poza

28-2011 Nadine Riedel, Hannah SchildbergHörisch

29-2011 Nicole Waidlein

30-2011 Dominik Hartmann, Atilio Arata

31-2011 Peter Spahn

32-2011 Fabian Wahl

33-2011 Giorgio Triulzi, Ramon Scholz and Andreas Pyka

34-2011 Claus D. MüllerHengstenberg, Stefan Kirn

35-2011 Andreas Pyka

36-2011 David Bell, Steffen Otterbach and Alfonso Sousa-Poza

37-2011 Lukas Scheffknecht, Felix Geiger

38-2011 Yin Krogmann, Ulrich Schwalbe
EARNINGS SHOCKS AND TAX-MOTIVATED INCOME-SHIFTING: EVIDENCE FROM EUROPEAN MULTINATIONALS

ECO

ICT

QUALITATIVES, RÄUMLICHES SCHLIEßEN ZUR KOLLISIONSERKENNUNG UND KOLLISIONSVERMEIDUNG AUTONOMER BDI-AGENTEN

VERHALTENSMODELLE FÜR SOFTWAREAGENTEN IM ICT PUBLIC GOODS GAME

ECO

ENGEL CURVES, SPATIAL VARIATION IN PRICES AND

DEMAND FOR COMMODITIES IN CÔTE D'IVOIRE

ASYMMETRIC OBLIGATIONS

ECO

CAUSES OF PERSISTENT PRODUCTIVITY DIFFERENCES IN THE WEST GERMAN STATES IN THE PERIOD FROM 1950 TO 1990

MEASURING SOCIAL CAPITAL AND INNOVATION IN POOR AGRICULTURAL COMMUNITIES. THE CASE OF CHÁPARRA PERU

DIE WÄHRUNGSKRISENUNION

DIE EURO-VERSCHULDUNG DER NATIONALSTAATEN ALS SCHWACHSTELLE DER EWU

ECO

DIE ENTWICKLUNG DES LEBENSSTANDARDS IM DRITTEN REICH - EINE GLÜCKSÖKONOMISCHE PERSPEKTIVE

ECO

R\&D AND KNOWLEDGE DYNAMICS IN UNIVERSITY-INDUSTRY

IK RELATIONSHIPS IN BIOTECH AND PHARMACEUTICALS: AN AGENT-BASED MODEL

ANWENDUNG DES ÖFFENTLICHEN VERGABERECHTS AUF MODERNE IT SOFTWAREENTWICKLUNGSVERFAHREN

ICT

AVOIDING EVOLUTIONARY INEFFICIENCIES

IK IN INNOVATION NETWORKS

WORK HOURS CONSTRAINTS AND HEALTH

$\mathrm{HCM}$

A BEHAVIORAL MACROECONOMIC MODEL WITH

ECO ENDOGENOUS BOOM-BUST CYCLES AND LEVERAGE DYNAMICS

INTER-FIRM R\&D NETWORKS IN THE GLOBAL PHARMACEUTICAL BIOTECHNOLOGY INDUSTRY DURING 1985-1998: A CONCEPTUAL AND EMPIRICAL ANALYSIS 
Nr.

39-2011 Michael Ahlheim, Tobias Börger and Oliver Frör

40-2011 Tobias Börger

41-2011 Ralf Rukwid, Julian P. Christ
RESPONDENT INCENTIVES IN CONTINGENT VALUATION: THE ECO ROLE OF RECIPROCITY

A DIRECT TEST OF SOCIALLY DESIRABLE RESPONDING IN CONTINGENT VALUATION INTERVIEWS

ECO

QUANTITATIVE CLUSTERIDENTIFIKATION AUF EBENE

IK DER DEUTSCHEN STADT- UND LANDKREISE (1999-2008) 
Nr.

Autor

Titel

42-2012 Benjamin Schön,

A TAXONOMY OF INNOVATION NETWORKS

IK

Andreas Pyka

43-2012 Dirk Foremny, Nadine Riedel

BUSINESS TAXES AND THE ELECTORAL CYCLE

ECO

44-2012 Gisela Di Meglio, Andreas Pyka and

VARIETIES OF SERVICE ECONOMIES IN EUROPE

IK

Luis Rubalcaba

45-2012 Ralf Rukwid, Julian P. Christ

INNOVATIONSPOTENTIALE IN BADEN-WÜRTTEMBERG:

IK

PRODUKTIONSCLUSTER IM BEREICH „METALL, ELEKTRO, IKT“ UND REGIONALE VERFÜGBARKEIT AKADEMISCHER FACHKRÄFTE IN DEN MINT-FÄCHERN

46-2012 Julian P. Christ,

INNOVATIONSPOTENTIALE IN BADEN-WÜRTTEMBERG:

IK Ralf Rukwid BRANCHENSPEZIFISCHE FORSCHUNGS- UND ENTWICKLUNGSAKTIVITÄT, REGIONALES PATENTAUFKOMMEN UND BESCHÄFTIGUNGSSTRUKTUR

47-2012 Oliver Sauter

ASSESSING UNCERTAINTY IN EUROPE AND THE

ECO US - IS THERE A COMMON FACTOR?

IK

SEN MEETS SCHUMPETER. INTRODUCING STRUCTUR
DYNAMIC ELEMENTS INTO THE HUMAN CAPABILITY APPROACH

49-2012 Harold ParedesFrigolett, Andreas Pyka

DISTAL EMBEDDING AS A TECHNOLOGY INNOVATION

IK NETWORK FORMATION STRATEGY

CYCLICALITY OF REAL WAGES IN THE USA AND GERMANY: NEW INSIGHTS FROM WAVELET ANALYSIS

ECO

Martyna Marczak Víctor Gómez

DIE DURCHSETZUNG VON SCHNITTSTELLEN

IK IN DER STANDARDSETZUNG:

FALLBEISPIEL LADESYSTEM ELEKTROMOBILITÄT

52-2012 Fabian Wahl

WHY IT MATTERS WHAT PEOPLE THINK - BELIEFS, LEGAL

ECO ORIGINS AND THE DEEP ROOTS OF TRUST

IK

Micha Kaiser

STATISTISCHER ÜBERBLICK DER TÜRKISCHEN MIGRATION IN BADEN-WÜRTTEMBERG UND DEUTSCHLAND

IDENTIFIZIERUNG UND ANALYSE DEUTSCH-TÜRKISCHER INNOVATIONSNETZWERKE. ERSTE ERGEBNISSE DES TGIN-

Andreas Pyka, Seda Aydin, Lena Klauß, Fabian Stahl, Ali PROJEKTES

Santircioglu, Silvia

Oberegelsbacher,

Sheida Rashidi, Gaye

Onan and Suna

Erginkoç

55-2012 Michael Ahlheim, Tobias Börger and Oliver Frör 
Nr. Autor

56-2012 Matthias Strifler Thomas Beissinger

57-2012 Peter Spahn

58-2012 Sibylle H. Lehmann

59-2012 Sibylle H. Lehmann, Philipp Hauber and Alexander Opitz

60-2012 Martyna Marczak, Víctor Gómez

61-2012 Theresa Lohse, Nadine Riedel
FAIRNESS CONSIDERATIONS IN LABOR UNION WAGE SETTING - A THEORETICAL ANALYSIS

INTEGRATION DURCH WÄHRUNGSUNION? DER FALL DER EURO-ZONE

TAKING FIRMS TO THE STOCK MARKET:

IPOS AND THE IMPORTANCE OF LARGE BANKS IN IMPERIAL GERMANY 1896-1913

POLITICAL RIGHTS, TAXATION, AND FIRM VALUATION -

ECO EVIDENCE FROM SAXONY AROUND 1900

SPECTRAN, A SET OF MATLAB PROGRAMS FOR SPECTRAL

ECO ANALYSIS

THE IMPACT OF TRANSFER PRICING REGULATIONS ON PROFIT SHIFTING WITHIN EUROPEAN MULTINATIONALS
ECO

ECO

ECO

ECO 
Nr. Autor

63-2013 David E. Bloom,

AGEING AND PRODUCTIVITY

$\mathrm{HCM}$

Alfonso Sousa-Poza

64-2013 Martyna Marczak,

MONTHLY US BUSINESS CYCLE INDICATORS:

ECO Víctor Gómez

A NEW MULTIVARIATE APPROACH BASED ON A BAND-PASS FILTER

65-2013 Dominik Hartmann,

INNOVATION, ECONOMIC DIVERSIFICATION AND HUMAN

IK

Andreas Pyka

DEVELOPMENT

66-2013 Christof Ernst,

CORPORATE TAXATION AND THE QUALITY OF RESEARCH

ECO

Katharina Richter and AND DEVELOPMENT

Nadine Riede

67-2013 Michael Ahlheim, Oliver Frör, Jiang Tong, Luo Jing and Sonna Pelz

68-2013 Michael Ahlheim, Friedrich Schneider

CONSIDERING HOUSEHOLD SIZE IN CONTINGENT VALUATION STUDIES

69-2013 Fabio Bertoni, Tereza Tykvová

WHICH FORM OF VENTURE CAPITAL IS MOST SUPPORTIVE OF INNOVATION?

EVIDENCE FROM EUROPEAN BIOTECHNOLOGY COMPANIES

70-2013 Tobias Buchmann, Andreas Pyka

THE EVOLUTION OF INNOVATION NETWORKS:

THE CASE OF A GERMAN AUTOMOTIVE NETWORK Pyka, J. A. La Poutré and A. G. de Kok

72-2013 Beatriz Fabiola López Ulloa, Valerie Møller and Alfonso SousaPoza

73-2013 Wencke Gwozdz, Alfonso Sousa-Poza, Lucia A. Reisch, Wolfgang Ahrens, Stefaan De Henauw, Gabriele Eiben, Juan M. Fernández-Alvira, Charalampos Hadjigeorgiou, Eva Kovács, Fabio Lauria, Toomas Veidebaum, Garrath Williams, Karin Bammann

HOW DOES SUBJECTIVE WELL-BEING EVOLVE WITH AGE? 
Nr.

Autor

74-2013 Andreas Haas, Annette Hofmann

75-2013 Yin Krogmann, Nadine Riedel and Ulrich Schwalbe

76-2013 Peter Spahn

77-2013 Sheida Rashidi, Andreas Pyka

78-2013 Benjamin Schön, Andreas Pyka

79-2013 Irene Prostolupow, Andreas Pyka and Barbara Heller-Schuh

80-2013 Eva Schlenker, Kai D. Schmid

81-2013 Michael Ahlheim, Tobias Börger and Oliver Frör

82-2013 Fabian Wahl

83-2013 Peter Spahn

84-2013 Daniel Guffarth, Michael J. Barber
RISIKEN AUS CLOUD-COMPUTING-SERVICES:

$\mathrm{HCM}$ FRAGEN DES RISIKOMANAGEMENTS UND ASPEKTE DER VERSICHERBARKEIT

INTER-FIRM R\&D NETWORKS IN PHARMACEUTICAL

ECO, IK BIOTECHNOLOGY: WHAT DETERMINES FIRM'S CENTRALITY-BASED PARTNERING CAPABILITY?

MACROECONOMIC STABILISATION AND BANK LENDING:

ECO A SIMPLE WORKHORSE MODEL

MIGRATION AND INNOVATION - A SURVEY

IK

THE SUCCESS FACTORS OF TECHNOLOGY-SOURCING THROUGH MERGERS \& ACQUISITIONS - AN INTUITIVE METAANALYSIS

TURKISH-GERMAN INNOVATION NETWORKS IN THE EUROPEAN RESEARCH LANDSCAPE

IK

CAPITAL INCOME SHARES AND INCOME INEQUALITY IN THE EUROPEAN UNION

ECO

THE INFLUENCE OF ETHNICITY AND CULTURE ON THE VALUATION OF ENVIRONMENTAL IMPROVEMENTS - RESULTS FROM A CVM STUDY IN SOUTHWEST CHINA -

DOES MEDIEVAL TRADE STILL MATTER? HISTORICAL TRADE CENTERS, AGGLOMERATION AND CONTEMPORARY ECONOMIC DEVELOPMENT

SUBPRIME AND EURO CRISIS: SHOULD WE BLAME THE ECO ECONOMISTS?

THE EUROPEAN AEROSPACE R\&D COLLABORATION

IK NETWORK

KARTELLBEKÄMPFUNG UND INTERNE KARTELLSTRUKTUREN

IK EIN NETZWERKTHEORETISCHER ANSATZ 
Nr.

Autor

86-2014 Stefan Kirn, Claus D.

INTELLIGENTE (SOFTWARE-)AGENTEN: EINE NEUE

ICT Müller-Hengstenberg HERAUSFORDERUNG FÜR DIE GESELLSCHAFT UND UNSER RECHTSSYSTEM?

87-2014 Peng Nie, Alfonso

MATERNAL EMPLOYMENT AND CHILDHOOD OBESITY IN $\mathrm{HCM}$ Sousa-Poza CHINA: EVIDENCE FROM THE CHINA HEALTH AND NUTRITION SURVEY

88-2014 Steffen Otterbach, Alfonso Sousa-Poza

JOB INSECURITY, EMPLOYABILITY, AND HEALTH:

$\mathrm{HCM}$ AN ANALYSIS FOR GERMANY ACROSS GENERATIONS

89-2014 Carsten Burhop, Sibylle H. LehmannHasemeyer

THE GEOGRAPHY OF STOCK EXCHANGES IN IMPERIAL GERMANY

ECO

90-2014 Martyna Marczak, OUTLIER DETECTION IN STRUCTURAL TIME SERIES Tommaso Proietti MODELS: THE INDICATOR SATURATION APPROACH

Andreas Pyka

92-2014 Bogang Jun, Joongho Lee

THE TRADEOFF BETWEEN FERTILITY AND EDUCATION: EVIDENCE FROM THE KOREAN DEVELOPMENT PATH

NON-FINANCIAL HURDLES FOR HUMAN CAPITAL ACCUMULATION: LANDOWNERSHIP IN KOREA UNDER JAPANESE RULE

94-2014 Michael Ahlheim, Oliver Frör, Gerhard Langenberger and Sonna Pelz

95-2014 Harold ParedesFrigolett, Andreas Pyka, Javier Pereira and Luiz Flávio Autran Monteiro Gomes

CHINESE URBANITES AND THE PRESERVATION OF RARE SPECIES IN REMOTE PARTS OF THE COUNTRY - THE EXAMPLE OF EAGLEWOOD

IK

IK

RANKING THE PERFORMANCE OF NATIONAL INNOVATION SYSTEMS IN THE IBERIAN PENINSULA AND LATIN AMERICA FROM A NEO-SCHUMPETERIAN ECONOMICS PERSPECTIVE

96-2014 Daniel Guffarth, Michael J. Barber 


\section{IMPRINT}

University of Hohenheim

Dean's Office of the Faculty of Business, Economics and Social Sciences Palace Hohenheim $1 \mathrm{~B}$

70593 Stuttgart | Germany

Fon $\quad+49(0) 71145922488$

Fax $\quad+49(0) 71145922785$

E-mail wiso@uni-hohenheim.de

Web www.wiso.uni-hohenheim.de 